\title{
Tabip Tuğgeneral Mustafa Nahit Tunaşar (1890-1970); Askerî ve Sivil Yaşamı, Siyasi ve Kültürel Faaliyetleri
}

\section{General Mustafa Nahit Tunaşar (1890-1970); Military and Civilian Life, Politicial and Cultural Activities}

\author{
Ridvan $\mathrm{BAL}^{*}$ (1)
}

*Dr., Ankara, Türkiye

ORCID: R.B. 0000-0002-3834-7304

Sorumlu yazar/Corresponding author: Rıdvan Bal,

Ankara, Türkiye

E-posta/E-mail: ridvanbal198413@gmail.com

Başvuru/Submitted: 05.10.2020 Revizyon Talebi/Revision Requested: 29.10.2020

Son Revizyon/Last Revision Received: 01.12 .2020

Kabul/Accepted: 10.12 .2020

Atıf/Citation: Bal, Ridvan. “Tabip Tuğgeneral Mustafa Nahit Tunaşar (1890-1970); Askerî ve Sivil Yaşamı, Siyasi ve Kültürel Faaliyetleri." Yakın Dönem Türkiye Araştırmaları-Recent Period Turkish Studies 39 (2021): 75-106. https://doi.org/10.26650/YTA2021-806061
ÖZ

Bu çalışmanın amacı, Tabip Tuğgeneral Mustafa Nahit Tunaşar'ın mesleki ve sosyal yaşamını incelemektir. Tunaşar, tıp fakültesi öğrencisi iken Balkan ve I. Dünya savaşları ile Millî Mücadele'ye katılmıştır. Tunaşar, yasal bir mevzuat olmamasından dolayı tıp alanında uzmanlaşamamıştır. Türkiye Cumhuriyeti'nin temel ideolojisi hakkında halkı bilgilendirmek, Atatürk ilke ve devrimlerini anlatarak toplumu aydınlatmaya çalışmıştır. Türk Ocaklarının bir üyesi olarak bu kuruluşu yaşatma mücadelesi dikkat çeken Tunaşar, emeklilik döneminde Demokrat Parti ve Adalet Partisi saflarında siyasetle de uğraşmış; iyi bir aile reisi, başarılı bir hekim ve örnek bir Türk aydını olarak sürdürdüğü yaşama $24 \mathrm{Kasım}$ 1970 günü veda etmiştir. Bu çalışma, esas olarak Tunaşar'ın kişisel arşiv kayıtları ile kızı Aysel Ceyhun ile görüşmeden elde edilmiş bilgilere dayanmaktadır.

Anahtar Kelimeler: Mustafa Nahit Tunaşar, Cumhuriyet Tarihi, Askerî Tibbiye, Türk Ocakları, Tire İlçesi

\section{ABSTRACT}

The aim of this study is to examine the professional and social life of General Mustafa Nahit Tunaşar. While he was the student of the medical faculty, he participated The National Struggle with the Balkan Wars and First World War. He could not specialize in the field of medicine, despite the lack of legal legislation. He studied to inform the public about the basic ideology of the Republic of Turkey and Ataturk's principles and revolutions. As a member of the Turkish Hearths, Tunaşar who was draws attention with the struggle to keep the Turkish Hearths, engaged in politics during his retirement on behalf of the opposition parties. As a good head of the family, a successful physician and an exemplary Turkish intellectual, he died on 24 November 1970. This study mainly is based on his personal archive records and interviews with his daughter-Aysel Ceyhun. Keywords: Mustafa Nahit Tunaşar, History of Turkish Republic, Military Faculty of Medicine, Turkish Hearths, Town of Tire 


\section{Extended Abstract}

Epidemic diseases, which are one of the biggest problems of human beings in almost every period of history, caused not only many people to die or become disabled in a short time but also triggered shocks in the internal order of the states and led to critical developments globally. These effects of the diseases are tried to end with the extraordinary struggle of the healthcare personnel and especially the physicians. In some periods, the facts shows that disease-related casulaties were higher than those in wars. Tackling epidemic diseases depends on factors such as finance, technology and scientific research. An absence of these factors has a negative impact on national health systems and causes a multitude of problems for physicians. Turkish physicians were affected by these kinds of problems during the wars before the foundation of the Republic of Turkey. Turkish physicians and especially military physicians have played an important role in the development process in the history of the Republic of Turkey, and one of these military physicians was General Mustafa Nahit Tunaşar.

The life of Tunaşar, who was a patriot and an intellectual physician, can be examined in three periods. The first period that includes childhood and studentship/cadetship is between 1890-1913 and was spent in Istanbul excluding the months when he participated in the Balkan Wars as a cadet. The second period begins with his graduation as a captain in 1913. He was appointed to Dimetoka Cholera Hospital (Dimotica, now in Greece) and there participated in the Balkan Wars. Later on he was appointed as the director of medical units around Kars (a city at Turkish Eastern Front) and during World War I, these units fought with the Russian and Armenian troops at different locations. He was in the same region during The Turkish War of Independence. After the war, he was ordered to collect intelligence about an important Kurdish tribe (named Shikak) and its leader Simko İsmail Agha. He effored to protect the health of both soldiers on the front line and civilian people behind the front line and in villages. Due to the legal regulations related to medical specialisation, some physicians were sent to European countries for specialist education. He was not one of them so he couldn't have the chance to be a specialist in a branch of medicine. He took place also in non-governmental activities while serving as a physician. One of them was membership of "Turkish Hearths" where he tried to inform the public about the new Turkish regime and principles of Atatürk. When it was decided to close this organization, he expressed his thoughts as a member in an effective way and wrote a special letter to the President of Turkish Hearths to prevent the organization from being closed. In 1944 he was promoted to the rank of Brigadier General and appointed to Erzurum and in 1947 he retired from the Army. 
The third period of Mustafa Nahit Tunaşar's life is about his post-retirement life in Tire, İzmir. Tunaşar, who had started to work as a freelance physician in his clinic, gained the respect and love of the people in a short time and served voluntarily in public organisations. Meanwhile he intended to enter politics in the opposition Democratic Party (DP). This preference can be perceived as a reaction to his unexpected retirement decision. As DP's Tire District manager and İzmir Provincial delegate, he played an active role in the party's political works. Despite being an opposition politician, he always managed to keep respect and friendship in his relations with the leading party and local officials. This feature prevented him from being harmed by some negative developments which his fellows faced during the military coup on 27 May 1960. Tunaşar, who left politics due to the military coup, entered politics again in the newly founded Justice Party (AP), with the start of the normalization process in 1961. In this new period, he became the local manager of the AP in the Tire district. Although he was selected as a candidate for the Republic Senate for a period, he could not be elected. Despite all negativities in his political life, he stated that he had fulfilled his expectations in terms of policy. Mustafa Nahit Tunaşar's life as a good head of the family, a successful physician and an exemplary Turkish intellectual ended on 24 November 1970. 


\section{Giriş}

İnsanlık tarihi, savaşlar ve doğal afetlerden kaynaklanan zararlar gibi salgın hastalıkların neden olduğu yıkımlara da tanık olmaktadır. Milyonlarca insanın hayatını kaybetmesine veya sakat kalmasına neden olan bu tehlike, küresel güç olarak bilinen devletlerin bile başlangıçta çaresiz kaldığı ve tedbir alamadığı düzeyde ortaya çıkabilmektedir. Günümüzde tüm dünyada olduğu gibi Türkiye Cumhuriyeti'nde de etkisini gösteren yeni bir salgın, sağlık personelinin ve özellikle hekimlerin özverili mücadelesi ile sonlandırılmaya çalışılmaktadır. Tıp fakültelerindeki öğrencilik yıllarından itibaren ülkeyi ilgilendiren konularda çekinmeden inisiyatif alan Türk hekimleri ve özellikle cephede görev yapabilecek şekilde eğitilen askerî hekimler, hemen her dönemde başarılarla dolu hizmetlerde örnek girişimlerde bulunmuşlardır. Genel olarak bu neslin gençlik dönemleri maddi olanaksızlıklar, salgın hastalıklar, küresel tehditler ve çeşitli silahlı çatışmalar gölgesinde sürmüş; tüm olumsuzluklara rağmen vatan sevgisi ve Türklük bilinci yaşatılmaya çalışılmıştır. Öğrencilik yıllarından itibaren savaşı yaşamış, cephe hattında ve gerisinde salgın hastalıkların neden olduğu yıkımlara çare aramış, en sıkıntılı ortamlarda gayretle hizmetler sürdürmüş bu hekimlerden biri de Tabip Tuğgeneral Mustafa Nahit Tunaşar'dır.

T1bbiyede öğrenci iken Balkan Savaşı'nın başlaması nedeniyle eğitimine ara verilerek askerî hastanelere görevlendirilen ve muharebelere katılan tıbbiyelilerden biri olan Tunaşar, savaş sonrası okuluna dönerek eğitimini tamamlayıp askerî hekim olarak kıtaya atanmıştır. Balkan Savaşlarının sona ermesinden kısa bir süre sonra Birinci Dünya Savaşı'nın başlaması nedeniyle uzun bir süre Doğu Anadolu'da cephe hattında hekimlik yapmıştır. Kurtuluş Savaşı süresince de aynı bölgede hizmete devam etmiş, barış zamanında vazifesini çeşitli kıta ve hastanelerde hekim ve yönetici olarak sürdürmüştür. Katıldığ üç ayrı savaştaki başarıları nedeniyle üç madalya ile taltif edilen Tunaşar, 1944 yılında tuğgeneralliğe terfi ettirilerek 3. Ordu komutanlık bölgesinin sağlık işlerinden sorumlu makama atanmıştır. Bir üst rütbeye terfi etmeyi beklediği günlerde sürpriz bir şekilde emekli edildiğini öğrenmiş ve 30 Ağustos 1947 tarihinde tuğgenerallikten emekli edilerek askerî hekimlik dönemini tamamlamıştır. Yeni yaşamına hekimlik mesleğine özveri ile devam etmiş, maddi beklenti içinde olmadan yaşadığı ilçe halkına yardımcı olmayı hedeflemiştir. Sivil toplum örgütlerinde kurucu ve yönetici olarak hizmetlerde bulunan, önce Demokrat Parti daha sonra ise Adalet Partisi'nin ilçe kurucuları arasında yer alarak siyasete de giren Tunaşar, 1970 yılında hayata veda etmiştir. Örnek bir aile reisi olmasının yanında devletine ve halkına her alanda hizmeti ön planda tutan bir askerî hekimin dünyası, yeni nesillere örnekler aktaracak ve saygıyla anılmasını gerektirecek yaşam mücadelesine sahne olmuştur. 


\section{Doğumu ve Öğrenim Hayatı ${ }^{1}$}

Osmanlı Devleti'ni siyasi, askerî ve ekonomik olarak büyük ölçüde etkileyen 18771878 Osmanlı-Rus Savaşı'nın (93 Harbi) acı sonuçlarından biri de Balkanlarda yaşayan binlerce Türk'ün Anadolu'ya sığınmak zorunda kalması oldu. Bulgaristan'ın Tuna boylarında yaşayan Türk ailelerinden Şahinzadeler, bu 1stıraplı göç sonunda Türkeli'ye $(\text { Avşa Adası) })^{2}$ yerleşti. Mustafa Nahit, Düyûn-1 Umûmiye (Düyun-u Umumiye) ${ }^{3}$ memuru olarak çalışmaya başlayan Mehmet Hilmi Bey ile Hatice Hanım'ın oğlu olarak 1890 yılında Türkeli'de doğdu. İlk ve orta okul eğitimi hakkında belge bulunamayan Mustafa Nahit'in yüksek eğitim almasını isteyen ailesi, onu İstanbul'a göndererek İstanbul Mercan İdadisi'nde okuttu. Devletin yönetim kademelerinde görev alacak üst düzey memurlar için çağdaş bir eğitim alt yapısı sağlayan bu liseden mezun olan Mustafa Nahit, Mekteb-i Mülkiye'ye girdi. Ancak babasının vefatı nedeniyle yatılı öğrenci olarak okumak zorunda kalınca 7 Kasım 1908'de İstanbul Tıp Fakültesi’ne askerî öğrenci olarak kaydoldu.

Türkiye'nin modern tıp alanında ilk atılımı olan İstanbul Tıp Fakültesi'nin ve askerî tıbbiyenin temelleri, 14 Mart 1827 'de Tıbhane-i Amire'nin açılması ile atıldı. Her dönem başarılı çalışmalar sergileyen ve "Gülhane" adıyla yaşayan tıbbiyenin Fransızca olan eğitim dili zamanla Türkçeye dönüştü. İhtiyaç üzerine Haydarpaşa'da yeni bir bina inşasına da başlandı. 1903'te açılışı yapılan bina, 1909'da fakülte reisi (dekanı) olarak Cemil (Topuzlu) Paşa'nın seçildiği yeni bir tıp fakültesi olarak askerî ve sivil tıbbiyelerin bir arada eğitim gördüğü ilim yuvasına dönüştü. ${ }^{4}$ Askerî öğrencilerin kıyafetlerinin özenle belirlenmesi, İngiliz kumaşından imal üniformaların kullanılması, bu okula verilen önemin bir göstergesiydi.

Mustafa Nahit Bey'in öğrencilik yıllarının bir bölümü, Osmanlı padişahları arasında olumlu ve olumsuz yönleriyle günümüzde dahi tartışılan Sultan II. Abdülhamit’in saltanat döneminde geçti. Bazı görüş sahiplerinin "Ulu Hakan", bazılarının ise "Kızıl Sultan"s ola-

1 General Mustafa Nahit Tunaşar'ın kızı Aysel Ceyhun ile Tunaşar ve ailesi hakkında yapılan görüşme, Ankara, 27.03.2020 (Çalışmada kullanılan kişisel bilgileri dâhil olmak üzere fotoğrafları, aile arşivini ve Tunaşar'a ait özel belgeleri teslim eden Sayın Aysel Ceyhun'a şükranlarımı sunarım).

2 Marmara Denizi'nin güneybatısında yer alan ve Balıkesir'in Marmara ilçesine bağlı bir ada olan Türkeli beldesinin ismi, 2005 yılında Avşa olarak değiştirilmiştir. Resmî Gazete, no. 25792, 19 Nisan 2005.

3 Düyûn-1 Umûmiye (Düyun-u Umumiye), Osmanlı Devleti'nden alacaklı olan devletlerin Osmanlı mali sistemini kontrol altına almak üzere 1881 yılında kurdukları teşkilata verilen isimdir. Enver Ziya Karal, Büyük Osmanlı Tarihi, C.IV, Ankara, Türk Tarih Kurumu Yayını, 2001, s. 427; Biltekin Özdemir, Osmanlı Devleti Dış Borçları, 2. bs., Ankara, Maliye Bakanlığ Yayını, 2010, s. 76.

4 Ayşegül Demirhan Erdemir, Tip Tarihi, İstanbul, Nobel Tıp Kitabevi, 2014, s. 130.

5 İlber Ortaylı, Osmanlı 'ya Bakmak, Osmanlı Çağdaşlaşması, İstanbul, İnkılâp Yayınları, 2016, s. 129-136. 
rak değerlendirdiği bu padişahın tezatlarla dolu uygulamaları, tıbbiyeliler arasındaki ilişkileri de etkiledi. Kızı Aysel Ceyhun'un babasının anılarından aktardığı şekliyle, bir gelenek olarak akşam yoklamalarında öğrencilerin hep bir ağızdan "Padişahım çok yaşa!" şeklinde dua ederken bazı öğrencilerin bunu "Padişahım baş aşağı!” şeklinde değiştirerek kendilerince tepki göstermesi, padişahın karikatürlerini okul içine sokan bazı öğrencilerin ispiyon edilerek cezalandırılması, dönemin olumsuz değerlendirmelerine örnekti. ${ }^{6}$

Daha iyi şartlarda eğitim öğretimin hedeflendiği yıllarda devletin parçalanma sürecine girmiş olması, tıbbiyelilerde üzüntü kaynağı oldu. Bir kurtuluş yolu arayışında olan ve çözüm için Türklerin her yönüyle geliştirilmesini sağlayacak bir reformun gerçekleştirilmesinin gerektiğini savunan askerî tıbbiyeliler, "190 Tıbbiyeli Türk Evladı" adına bir bildiri hazırlayarak Türkçü aydınlarla görüştüler. Bu bildirinin de etkisiyle 25 Mart 1912 günü Türkiye'nin en köklü sivil toplum örgütü olan Türk Ocağ1 kuruldu. ${ }^{7}$ Günlük siyasi gelişmelerden uzak durmaya özen gösteren oluşum, dönemin tanınmış aydınları tarafından da desteklenen eğitici programlarla Türk milliyetçiliği üzerine odaklanmış bir yapı oluşturmaya çalıştı. Tıbbiyelilerin de çoğunlukla takip ettiği bu gelişmeler, Balkan Savaşı nedeniyle genel seferberlik ilan edilmesi ve okulun tatil edilmesiyle bir süre askıya alınmak zorunda kaldı.

1912 yılının ekim ayından itibaren fakültenin hocaları ve son sınıf öğrencileri cephedeki birliklere atandılar. Kolera salgınının artış göstermesiyle küçük sınıf öğrencileri de yardımcı sağlık personeli olarak çeşitli sahra hastanelerinde görevlendirildi. Mustafa Nahit Bey, 23 Ekim 1912 ile 15 Aralık 1912 tarihleri arasında Çerkezköy Menzil Komutanlığı emrinde ve İstanbul Taşkışla Hastanesi’nde, 15 Aralık 1912 ile 14 Mayıs 1913 tarihleri arasında Selimiye Redif Fırkası'nda ${ }^{8}$ tabur hekimliği ve firka başhekim yardımcısı olarak görev yaptı. Genel seferberliğin kaldırılmasıyla fakültenin hocaları, asistanları ve öğrencileri okula geri döndüler. Mustafa Nahit Bey, 17 Temmuz 1913 tarihinde askerî tıbbiye eğitimini tamamlayarak (1913-30) sicil numarasıyla yüzbaşı rütbesi ile mezun oldu ve meslek hayatına başladı. ${ }^{9}$

6 Aysel Ceyhun ile yapılan 27.03.2020 tarihli görüşme.

7 İsmail Acar, “1912'den 2012'ye Türk Ocakları, Tarihi-Çalışmaları-Görüşleri”, Türk Yurdu, C.32, S.295, 2012 , s. 100.

8 Redif: Zorunlu askerlik hizmetini tamamladıktan sonra yedek olarak bekleyen, seferberlikte silah altına alınarak düzenli ordu birlikleri gibi kullanılmaya hazır askerlere ve bunlardan oluşan birliklere verilen ad. Balkan hezimeti sonrasında ordunun yeniden düzenlenmesi sürecinde Alman Islah Heyeti’nin tavsiyesi ile yürürlükten kaldırıldı. Naci Çakın, "Redif Teşkilatı”, Askerî Tarih Bülteni, S.26, 1989, s. 31, 48. Fırka: Günümüzdeki karş1lı̆̆ tümen olarak belirtilebilecek askerî birlik.

9 Türk Hekimleri Dostluk ve Yardım Cemiyeti, Şeyhületibba, 50 Sene ve Daha Fazla Tababet Hayatı Yaşayan Hekimlerimizin Jübilesi, İstanbul, Şevket Ünal Matbaası, 1964, s. 65. 


\section{Askerî Hekimlik Yılları ${ }^{10}$}

Askerî tıbbiyeden mezun olduktan sonra Balkan Savaşı'nın devam etmesi nedeniyle 2 Ağustos 1913 'te ilk görev yeri olan Dimetoka Kolera Hastanesi'ne atandi. Daha sonra bir dönem 28. Firka Seyyar Hastanesi'nde de çalışan Tabip Yüzbaşı Mustafa Nahit Bey, savaşın sona ermesiyle birlikte 18 Kasım 1913’te cepheden alınıp İstanbul Gülhane Askerî Hastanesi'ne gönderildi. ${ }^{11}$ Mesleki gelişim çalışmalarını tamamlayan ve kursu başarıyla bitiren Mustafa Nahit Bey, 11 Temmuz 1914'te şark hizmetini yapmak üzere 11. Kolordu Komutanlığ 1 emrine atandı. Bu atama, genç hekimin Birinci Dünya Savaşı'na Doğu (Kafkas) Cephesi'nde katılacă̆ı anlamına gelmekteydi.

\subsection{Birinci Dünya Savaşı Yılları}

Doğu Cephesi, Osmanlı Devleti'nin Birinci Dünya Savaşı'nda açtığı ilk cephedir. Özellikle lojistik bakımdan kötü durumda olmasına rağmen 93 Harbi’nde kaybedilen toprakların geri alınması ve Orta Asya Türk toplumları ile yakın ilişkiler kurulması hedefleri, bu cephenin açılmasının nedenleri arasında yer aldı. 3. Ordu birliklerinin görev yaptığı Doğu Anadolu Bölgesi, Rus ordularına karşı şiddetli muharebelerin cereyan ettiği bir cephe olmasının yanında bir hekim için önem arz eden salgın hastalıklar ve neden olduğu zayiat yönüyle de önemli bir cephe olarak kayda geçti. Salgın hastalıklarından ölüm sayısının en fazla olduğu bölge, dört yıllık süre sonunda 116.182 ölümün gerçekleştiği 3. Ordu Komutanlığı bölgesi oldu. ${ }^{12}$ Mustafa Nahit Bey de 3 Ağustos 1914'te bu orduya bağlı olan 11. Kolordu emrine katılış yaptı.

Üç yıl kadar görev yaptı̆ğ 11. Kolordu'nun değişik alaylarında muharebelere katılan Mustafa Nahit Bey'in burada görevlendirildiği ilk birliği 34. Topçu Alayı, katıldığı ilk muharebeler Köprüköy ve Azap muharebeleri oldu. ${ }^{13}$ 7-12 Kasım 1914 tarihleri

10 Muvazzaf subaylık dönemine ait bilgiler, “Ordu Zabitan ve Memurlarına Mahsus Resmî Tercümeihal Kâğıdı” olarak hazırlanmış ve ilgili sicil amirince onaylanmış 12 bölümlü belgeden alınmıştır. Örnek bir sayfa için bkz. Ek-1: Mustafa Nahit Tunaşar'a Ait Tercümeihal Kağıdı.

11 Adı geçen yıllarda Osmanlı Devleti'nde hekimlerin uzmanlık alanlarına yönelik eğitim ve uygulamasını açıklayan bir mevzuat bulunmamaktaydı. T.C.' de uzmanlık eğitimi ile ilgili ilk düzenleme ise 8 Mayıs 1929 tarihinde yürürlüğe girmiş olan "Tababet ve İhtisas Vesikaları Hakkında Nizamname” ile oluşturulmuştur. Can Öner, "Tıpta Uzmanlık Mevzuatında Aile Hekimliği Uzmanlığının Evrimi”, Türkiye Aile Hekimliği Dergisi, C.19, S.4, 2015, s. 165. Dolayısıyla günümüzdeki manada tıpta uzmanlık kavramı olmadığından Mustafa Nahit Tunaşar da herhangi bir alanda uzmanlık yapamamıştır.

12 Hikmet Özdemir, Salgın Hastalıklardan Ölümler, 1914-1918, Ankara, Türk Tarih Kurumu Yayını, 2005, s. 141; Genelkurmay Başkanlığı, Türk Silahlı Kuvvetleri Tarihi, Birinci Dünya Harbi, İdari Faaliyetler ve Lojistik, C.IX, Ankara, Genelkurmay Yayını, 1985, s. 299.

13 Tunaşar'ın seferî hizmetleri ve katıldığı muharebeleri gösteren onaylı belge için bkz. Ek-2: Mustafa Nahit Tunaşar'a Ait Seferî Hizmetler ve Katıldığı Muharebeler Çizelgesi. 
arasında cereyan eden Köprüköy muharebelerinin başlangıcında Rus birliklerinin başarıs1 görüldü. Ancak süratle yeniden tertiplenip karşı taarruza geçen 3. Ordu birlikleri Rus ilerleyişini durdurarak geri çekilmelerini sağlad1. ${ }^{14}$ Köprüköy muharebelerinde başarı elde ettiğini değerlendiren 3. Ordu Komutanlığı, bu başarıyı sürdürmek ve Rus birliklerini imha etmek üzere Azap yönünde ileri harekete geçti.

16-20 Kasım tarihlerindeki Azap muharebelerinde de Türk birliklerinin taktik başarılar kazandığ 1 ve olumsuz koşullara rağmen Rus taarruzlarını geri atabileceği görüldü. Ne yazık ki komuta kademesinin ileri görüşlü olmayıp birliklerin geride tertiplenmesi için emir vermesiyle Rus kuvvetlerine toparlanma zamanı tanındı ve imha harekâtı gerçekleştirilemedi. ${ }^{15}$

Aynı kolordunun 34. Piyade Alayı'nda Kuzuçam ve Erzurum Müstahkem Mevkii'nde cereyan eden muharebelerde yer alan Mustafa Nahit Bey, 54. Piyade Alayı'nda da Gümüşhane Tekke Sırtları ve Kelkit muharebelerinde görevlendirildi. Askerî safahat belgesinde "yaralanmamış ve esir düşmemiştir"16 notu ile bu bölgedeki muharebelerden başarıyla çıktı. Balkan ve Birinci Dünya savaşlarına katılım ve başarıları nedeniyle hak ettiği madalyalardan Harp Madalyası'nı Mart 1916'da, Gümüş Liyakat Madalyası'nı ise Temmuz 1917’de aldı.

Üç aylık bir süre 2. Kafkas Kolordusu 25. Seyyar Hastane tabipliği yapan Mustafa Nahit Bey, 10 Kasım 1917'den itibaren 11. Kafkas Fırkası'nın sıhhiye bölüğüne atandı. Bu bölükteyken Kars, Gümrü, Karakilise, Norşin ${ }^{17}$ ve Nahcivan'da Ermeni kuvvetlerine karşı savaştı. Mustafa Nahit Bey, İran'da Dikmetaş ve Türkmençayı bölgelerinde İngilizlere karşı girişilen harekâtlarda da yer aldı. Bolşevik Devrimi sonrası Sovyet Rusya'nın girişimi ile başlayan barış görüşmeleri neticesinde 3 Mart 1918'de BrestLitovsk Antlaşması'nın imzalanması ile Kars, Ardahan ve Batum Osmanlı Devleti'ne geri verildi; Rus orduları Doğu Anadolu' da işgal ettiği tüm yerlerden çekildi. ${ }^{18} \mathrm{Ne}$ var ki

14 Genelkurmay ATASE Başkanlığı, Birinci Dünya Harbi’nde Türk Harbi, Kafkas (Doğu) Cephesi, 3. Ordu Harekât,, Ankara, Genelkurmay Basımevi, 1978, s. 193-195.

15 Sayim Türkman, "Birinci Dünya Savaşı’na Giriş Süreci, Doğu (Kafkas) Cephesi: Köprüköy ve Azap Muharebeleri”, Turkish Studies-History, C.15, S.1, 2020, s. 296.

16 Ek-2: Mustafa Nahit Tunaşar'a Ait Seferî Hizmetler ve Katıldığı Muharebeler Çizelgesi.

17 Karakilise yerleşim merkezinin adı Kâzım Karabekir zamanında Karaköse olarak değiştirilmiş, 1935 yılında Ağrı adıyla il merkezi olarak belirlenmiştir. Bilal Tunç-Fatih Özçelik, "Cumhuriyet Döneminde Ağrı Nüfusundaki Gelişmeler (1927-1980)", Insan ve Toplum Bilimleri Araştırmaları Dergisi, C.6, S.3, 2017, s. 2134. Norşin yerleşim merkezi, Bitlis'e bağlı bir köy iken 1926'da nahiye statüsü almış ve adı Çukur olarak değiştirilmiştir. 1987 yılında ise ilçe olup Güroymak adını almıştır. İbrahim Baz, "Osmanlı'dan Cumhuriyet'e Norşin Dergâhı ve Şeyh Abdurrahman-1 Tağii”, Tasavvuf İlmî ve Akademik Araştırma Dergisi, C.34, S.2, 2014, s. 74.

18 Fahir Armaoğlu, 20. Yüzyıl Siyasi Tarihi, 1914-1918, Ankara, Türkiye İş Bankası Yayını, 1983, s. 140. 
Rusya'da yaşanan iç gelişmeleri iyi değerlendiren İngiltere'nin, Rusların kontrolündeki toprakları da ele geçirmek ve asıl hedefi olan Bakü’ye yönelmek için girişimlerde bulunması, bölgedeki çatışmaların sürmesine neden oldu. ${ }^{19}$

Osmanlı kuvvetlerinin Doğu Cephesi'nde kazandığı başarılar, 30 Ekim 1918 tarihli Mondros Ateşkes Antlaşması gereği değerini kaybetti. Antlaşmada yer alan İran'ın kuzeybatısı ve Kafkasya'daki Türk askerlerinin geri çekilmesi maddesine dayanarak 1914’teki sınırlara çekilme işlemi yerine getirildi. Birinci Dünya Savaşı’nın sona ermesi ile askerî teşkilatlanma sürecinde yeni ve özel bir aşamaya geçildi. 3. Ordu Komutanlığı bölgesinde kalan Mustafa Nahit Bey, 12 Temmuz 1919'da Beyazit'taki 11. Kafkas Firkası Hastanesi tabipliğine atand1.

\subsection{Millî Mücadele Yılları}

Vatan topraklarının işgale başlanması karşısında kurtuluş için Anadolu'da başlayacak bir ulusal direnişi tek çare olarak gören Mustafa Kemal, aradığı fırsatı 9. Ordu Kıtaatı müfettişliğine (daha sonra 3. Ordu müfettişliği olarak değiştirildi) atamasının yapılması ile sağladı. Samsun'a ayak bastığı günden itibaren hem kendi bölgesindeki hem de diğer sorumluluk alanlarındaki komutanlıklara telgraf çekerek diriliş mesajları veren Mustafa Kemal'in bu girişimleri Havza Genelgesi'nden sonra artış gösterdi. İtilaf Devletlerinin de baskısıyla 8/9 Temmuz gecesi Mustafa Kemal'e resmî görevinin sonlandırıldığı tebliğ edildi. Buna cevap olarak vazifesiyle beraber askerlik mesleğinden de ayrıldığını bildiren Mustafa Kemal, tüm yetkileri elinden alınmış bir kişi olmasına rağmen halkın inanç ve desteği ile hedefine doğru yürümeye devam etti. Doğu Anadolu Bölgesi'nde kaybedilen vatan topraklarının başarılı muharebelerle geri alınması ve bir ulusal direnişe moral desteği sağlanması, Erzurum'daki 15. Kolordu komutanlığ vini yürüten ve Mustafa Kemal'in görevinden azledilmesi ile boşalan 3. Ordu müfettişliğini de idare eden Kâzım (Karabekir) Paşa’nın girişimleri ile sağlandı. 15 Haziran 1920’de Türkiye Büyük Millet Meclisi Hükûmetince oluşturulan Doğu Cephesi Komutanlığı'na ordu komutanı yetkisiyle atanan Kâzım Paşa, 1923 yılı sonuna kadar vazifesini başarıyla yürüttü. Yeni görev yerinde terfi eden ve 16 Kasım 1919'da kıdemli

19 İngilizler, Türklerin bölgedeki kontrolünü engellemek üzere Ermenileri, Kürt aşiretlerini ve Nesturileri örgütlemeye başladı. İlginç bir iş birliği olarak, bölgeden henüz ayrılmamış olan Rus General Baratof, Bolşevik Devrimi nedeni ile geri dönmeyen Rus askerleri ve bölgedeki Ermeni, Nesturi gruplarla İngilizler gelinceye kadar bölgeyi kontrol etmeye devam etti. Özellikle Tebriz'de bulunan Ermeniler ile İngiliz birliklerinin faaliyetlerine engel olunması için 3. Ordu'nun en kısa sürede Tebriz'e ilerlemesi emredildi. Eylül 1918'de bölgede yaşanan çatışmalar sonrasında İngiliz birliklerinin ve kontrollerindeki Ermenilerin yenilerek Meyane istikametinde geri çekilmeleri, Tebriz'in Türk birlikleri kontrolüne girmesiyle güvenlik sağlanmış oldu. Barış Metin, Birinci Dünya Savaşı 'nda İran Coğrafyasında Etnik, Dini ve Siyasi Nüfuz Mücadeleleri, Ankara, Berikan Yayınevi, 2012, s. 186. 
yüzbaşı olan Mustafa Nahit Bey, Millî Mücadele yıllarında da aynı bölgede görev yaptı. Ekim 1920'de Ermenilere karşı yürütülen Iğdır muharebelerine katıldı, Beyazıt'tan sonra baştabip olarak yeni açılmış olan Ardahan Hastanesi'ne atandı. Hastane görevini bir yıl kadar sürdürüp 1 Mart 1922'den itibaren Caksu ve Kızılçakçak hudut alaylarında tabip olarak görevlendirildi. ${ }^{20} \mathrm{Bu}$ bölgede dikkat çekici bir vazifesi ise Kâzım Paşa'nın özel emri gereği Şikak Aşireti Reisi Simko lakaplı İsmail Ağa ve aşiret hakkındaki istihbarat çalışmaları oldu. ${ }^{21}$

Osmanl1-İran sınırının uzun süre net bir şekilde belirlenememesi, Sovyet Rusya ve İngiltere'nin İran topraklarındaki nüfuz çatışmaları, Doğu Anadolu'ya komşu Kürt aşiretlerinin dönemsel eylemleri bölgede istikrarsızlığın kaynaklarını oluşturdu. Adı geçen devletlerin karşı karşıya gelmesine neden olan aşiretlerden biri de Şikak Aşireti idi. Geçmişte bir dönem Osmanlı Devleti’ne bağlı olmuş ve sonraları İran topraklarında müstakil yaşamış Şikak Aşireti, her firsatta bölgede çetecilik-eşkıyalık eylemlerinde ön plana çıkmıştı. Bölgedeki en büyük aşiretlerden olan Şikak Aşireti, liderleri Simko İsmail Ağa döneminde de kayda değer eylemlerde bulundu. ${ }^{22}$ Bölgedeki birliklerin Mondros Ateşkes Antlaşması gereği bulundukları yerleri terk ederek geri çekilmek zorunda kalmasıyla bölgede ciddi bir otorite boşluğu oluştu. İran tarafından da kontrol edilemeyen sınır boyunda aşiretlerin hareketi kolay hale geldi.

Doğu Cephesi Komutanı Kâzım Paşa, başarılı sevk ve idaresi ile güvence altına ald1ğ1 bölgede ve doğu sınırlarında, Millî Mücadele süresince de bir ayaklanma girişimine firsat tanımamaya çalıştı. Van Hastanesi'nde görevli olan ve 1 Mart 1921'de binbaşılığa terfi eden Mustafa Nahit Bey'i, aşiret halkına insani yardım ve Simko İsmail Ağa'nın planlarını öğrenmek amacıyla Dilman, Urmiye (Rumiye) bölgesine görevlendirdi. Yanındaki Kürtçe bilen erler vasıtasıyla aşiret hakkında başarılı istihbarat çalışmaları yapan Mustafa Nahit Bey, aşiret halkına tıbbi yardımda bulunurken muhtemel bir ayaklanma girişiminin önlenmesine de katkı sağladı. ${ }^{23}$

20 Kars'a bağlı Kızılçakçak ilçesinin adı 1961'de Akyaka olarak değiştirilmiştir. “İlçemizin Tarihçesi”, (Çevrimiçi), http:// www.akyaka.gov.tr/ilemizin-tarihesi, 30 Ekim 2020. Ardahan ili Posof ilçesine bağlı Caksu köyünün adı, 1968'de Yurtbekler olarak değiştirilmiştir. İçişleri Bakanlığı İller İdaresi Genel Müdürlüğü, Köylerimiz, Ankara, Başbakanlık Basimevi, 1968, s. 627.

21 Türk Hekimleri Dostluk ve Yardım Cemiyeti, Şeyhületibba, 50 Sene..., s. 65.

22 Fatih Ünal, “Şikak Aşireti ve Reisi Simko Lakaplı İsmail Ağa'nın Faaliyetleri”, İstanbul Üniversitesi Edebiyat Fakültesi Tarih Dergisi, S.44, 2006, s. 175.

23 Türk Hekimleri Dostluk ve Yardım Cemiyeti, Şeyhületibba, 50 Sene.., s. 65. 


\subsection{Cumhuriyet Dönemi Görev Yerleri ve Çalışmaları}

Lozan Barış Antlaşması'nın imzalanmasından sonra ordunun barış şartlarına geçiş hazırlıkları kapsamında 5 Ağustos 1923 tarihli "Hazar Kuruluşu ve Konuş Projesi” hayata geçirildi. Üç ordu müfettişliği, dokuz kolordu, on sekiz piyade tümeni ve üç süvari tümeninden oluşan yeni yapılanma, personelin rütbe ve görev safahatı da dikkate alınarak çok sayıda yer değişikliğini de beraberinde getirdi. Doğu Anadolu'daki görev süresini tamamlayan Binbaşı Mustafa Nahit Bey 1 Eylül 1923'te İstanbul İtfaiye Alayı'nın 3. Tabur hekimliğine atandı. Burada kısa bir süre çalıştıktan sonra Süvari Binicilik ve Tatbikat Okulu tabibi olarak görevlendirildi. 61. Fırka Topçu Alayı tabipliğinde iken yarbay olup 8 Eylül 1928'de Kırklareli Hastanesi baştabibi olarak atandı.

1929 yılında Kırklareli'nde tabip yarbay olarak görev yaparken Nadire Kerim Hanım ile evlendi. Selanik-Avrethisar doğumlu olan Nadire Kerim Hanım, babası komitacılar tarafından öldürüldüğü için annesi ve ağabeyi ile Balkan Savaşları esnasında Anadolu'ya göç etmiş bir aileye mensuptu. 1930 yılında Aysel isimli kızları, 1938 yılında da Seyhun isimli oğulları dünyaya geldi. ${ }^{24} 21$ Haziran 1934 ve 2525 sayılı yasa ile Soyadı Kanunu kabul edilince, sülalesinin Anadolu'ya göç etmeden önce yaşadığı Tuna boylarını anmak için şehir, belde anlamına gelen "şar" sözcügü ile birleşen "Tunaşar" sözcüğünü soyadı olarak belirlediler. Mustafa Nahit Tunaşar'ın aile içi davranışları, günlük yaşamı ve hayata bakış şekli gibi konularda bilgi kaynağı olarak kızına bıraktığı kişisel notları ve kızı ile yapılan görüşmeden elde edilen bilgilerden faydalanılmıştır.

Kırklareli'ndeki dört yıllık hizmet süresinden sonra Niğde, Isparta ve Konya'da da görev yapan Mustafa Nahit Bey'in bir sonraki ataması Ankara'ya oldu. Gülhane Hastanesi üst subay kadrosunda iken 30 Ağustos 1937'de albay olup daha sonra ise Ankara Hastanesi'nde baştabip yardımcılı̆̆ 1 ve Sıhhiye İşleri Dairesi'nde 3. Şube müdürlüğü yaptı. Kızı Aysel Ceyhun'un babası hakkındaki düşünce ve değerlendirmelerini, genellikle yedi sekiz yaşlarından itibaren ayrıntılı olarak anımsadığı görülmüştür. Bu bağlamda 1938'de Ankara'ya atanan Tunaşar'ın bu yıllarda özellikle ev kirası ödemeleri nedeniyle maddi sıkıntı çektiği, 219 lira olan maaşıyla önce 70 liralık bir ev kiraladı$\breve{g}$ 1; ancak zorlanma nedeniyle bir süre sonra 45 liraya Konur Sokak'ta başka bir eve taşındıkları belirtilmiştir. Tüm maddi sıkıntılara rağmen çocuklarının en iyi şartlarda eğitim alabilmesi için her türlü fedakârlığı yaptığı özellikle aktarılmıştır. ${ }^{25}$

24 Tunaşar Ailesi'nin Nüfus Kayıt Örneği, 07.03.1995.

25 Aysel Ceyhun ile yapılan 27.03.2020 tarihli görüşme. 
Tıp bilimindeki gelişmeleri her firsatta takip etmeye çalışan, bu konudaki bilimsel yayınlara abone olan Tunaşar, askerî tıp konularındaki bilgi birikimi ve tecrübelerini paylaşmak amacıyla makale çalışmalarında da bulundu. Her türlü muharebe ortamında askerî sağlık personelin kritik vazifelerini açıklamak, özellikle zor koşularda muharebe dışı kalma durumundaki askerlere tatbik edilecek sıhhi işlemleri anımsatmak üzere bilgilerini paylaştı. Ceride-i Tıbbiye-i Askerîyye ${ }^{26}$ adıyla 1871 yılında yayın hayatına başlayan, tıp ve eczacılık konularında yazılı ve görsel yayınların yer aldığı Askerî Sihhiye Mecmuası'nda İngilizce olarak iki makalesi yayımlandı.

1939 yılında kaleme aldığı makalesinde, sadece düşmanla değil zorlu arazi şartlarıyla da mücadele esnasında ihtiyaç duyulan sağlık hizmetlerini inceledi. Bu çalışması, derginin 68. sayısında "Principles In The Health Service In Mountain Warfare” başl1ğıyla yayımlandı. 1940 yılındaki makalesinin konusu gece yapılan muharebelerde ve ani hücumlarda sağlık hizmetleriydi. Bu makalesi de derginin 69. sayısında "Health Service In Sudden Attacks And Night Combats" başlı̆̆ ile yer ald1. ${ }^{27}$ Muharebe ortamında askerî sağlık hizmetlerinin yürütülebilmesinin deneyimli askerî sağlık personeli ve özel uygulamalarla sağlanabileceğini özetleyen her iki makalesi de ABD Silahlı Kuvvetler Sağlık Kütüphanesi’nde kataloglandı.

Ankara'daki görev süresini tamamlayarak 1942'de Hadımköy'deki 4. Kolordu baştabipliğine atanması nedeniyle Tunaşar ailesi İstanbul'a taşındı. İkinci Dünya Savaşı'na girmemiş olsa da savaş süreci Türkiye'yi derinden etkiledi. Çeşitli sııııntılarla karşılaşan her aile gibi Tunaşar ailesi de bu süreçte savaş koşullarıyla yaşamak zorundaydı. Hadımköy’de görev yapmasına rağmen ailesi için Fatih’te bir ev kiralayan Tunaşar, mesai şartları gereği evine ancak on beş günde bir giderek eşi ve iki çocuğunu görebildi. Günlük ihtiyaçların karneyle karşılandığı, geceleri evlerde karartma uygulanan zor günlerde durum daha da kritik bir hal alınca Anadolu yakasına geçmesi gereken aile için Erenköy Sahra-yı Cedid'deki bir konağın bahçesinde bir ev bulundu. Yaşamında önemli bir safha olan terfi heyecanını 1944'te bu evde yaşadı. 30 Ağustos 1944 tarihinde generalliğe terfi ettiği haberini, ülkenin içinde bulunduğu sıkıntılı İkinci Dünya Savaşı akşamlarından birinde öğrendi. Evlerinde ailecek radyo başına toplanmış olan Tunaşarların

26 Hamit Pehlivanlı, "Son Dönem Tarih Araştırmalarında Askerî Gazete ve Süreli Yayınların Yeri”, Atatürk Araştırma Merkezi Dergisi, C.XXI, S.61, 2005, s. 253; Hakan Bacanl1-Efdal As, (Türk Tıp Tarihinin En Uzun Süreli Bilimsel Yayını) Ceride-i Tıbbiye-i Askerîye'den Gülhane Tıp Dergisi'ne (1872-2017) Tarihçe/Dizin, 2018 (Çevrimiçi), s. 1, http://sbu.edu.tr/FileFolder/Dosyalar/eb408a43/2018_10/cerideitibbiyeyiaskeriyeden.pdf, 21 Haziran 2020.

27 Nahid Tunaşar, "Principles In The Health Service In Mountain Warfare", Askerî Sihhiye Mecmuası, S.68, 1939, s. 75-81; Nahid Tunaşar, "Health Service In Sudden Attacks And Night Combats", Askerî Sihhiye Mecmuası, S.69, 1940, s. 7-9; Index-catalogue of the Library of the Surgeon General's Office, United States Army, V.XI, Washington, Government Printing Office, 1955, s. 332, 655. 
heyecanlı bekleyişi, Tabip Albay Mustafa Nahit Tunaşar isminin tuğgeneralliğe terfi edenler arasında olduğunun duyurulmasıyla mutlu sonland1. ${ }^{28}$ Sevinç tepkisini yumruğunu masaya vurarak “oldu bu iş" şeklinde gösteren Nahit Paşa, yeni görev yeri olarak emredilen 3. Ordu sıhhiye müfettişliğine başlamak üzere Erzurum'a hareket etti. Gençlik yıllarını savaşlarla geçirdiği bu bölgede tabip tuğgeneral olarak göreve başladı.

Orgeneral Mustafa Muğlalı komutasındaki 3. Ordu'nun karargâhının bulunduğu Erzurum'da, aynı zamanda 9. Kolordu karargâhı da yer almaktaydı. Nahit Paşa, Birinci Dünya Savaşı'nda çeşitli cephe ve bölgelerinde görev yaptığı Doğu Anadolu'da, bu kez de Soğuk Savaş döneminin Türk-Rus gerginliğine tanıklık etti. Birinci Dünya Savaşı'nda cephede ve cephe gerisinde yaşanan sağlık sorunlarını, salgın hastalıkların neden olduğu kayıpları çok iyi bilen hekimlerden biri olarak o dönem yaşanan sıkıntıları hatırlatmak ve hayatını kaybeden sağlıkçıları unutturmamak için girişimleri oldu. Mareşal Çakmak Hastanesi'nin girişine, Doğu Cephesi'nde şehit olmuş 125 tabip, 25 eczac1, 6 cerrah, 1 diş hekimi ve 7 tıp öğrencisi olmak üzere toplam 164 askerî sağlık personelinin isimlerinin yazılı olduğu mermer bir kitabe diktirdi. ${ }^{29}$ Müfettişlik görevi süresince ordu birliklerinin sağlık konuları ve tıbbi hizmetlerinin en üst düzeyde karşılanabilmesi için gereken tedbirleri aldı.

1947 yılının yaz aylarında tümgeneralliğe terfi beklentisi içinde olan Nahit Paşa, terfi sırasında olan subaylar için uygulamaya konan bir kararla sağlık raporu alması için Ankara'ya sevk edildi. Gülhane Askerî Hastanesi'nde ayrıntılı olarak muayene edildikten sonra hastane sağlık kurulundan “sağlam” raporu alıp Erzurum’a dönme hazırlıklarına başladı. Ankara Garı'nda bilet işlemlerini hallettikten sonra Erzurum'a hareket etmek üzere iken Gülhane Askerî Hastanesi'nden gelen bir mesajla hastaneye geri çağırıldı. Eksik işlem yapıldığg için tekrar muayene edileceği tebliğ edilen Nahit Paşa, bu uygulamadan ciddi derecede rahatsızlık duydu. Bir müddet daha Ankara'da kalması gerektiğinden eşine mektup yazarak yeniden muayene için geri çağırılması nedeniyle üzüntüsünden ağladığını ve kendisine suçlu muamelesi yapıldığını hissettiğini belirtti. ${ }^{30}$ Tekrar hastaneye gittiğinde çok kısa bir süre önce kendisine sağlam raporu veren meslektaşlarının hazırladı̆̆ı "uygun değildir" raporu ile muayene işlemini tamamlamış oldu. Sağlık sorunu gerekçe gösterilerek bir üst rütbeye terfi ettirilmeyen Mustafa Nahit Tunaşar, 30 Ağustos 1947 tarihinde emekliye sevk edildi. Olgunlukla karşıladığı emeklilik kararını tebellüğ edip Erzurum'dan ayrıldı.

28 Aysel Ceyhun ile yapılan 27.03.2020 tarihli görüşme.

29 Hikmet Özdemir, Salgın Hastalıklardan..., s. 297.

30 Aysel Ceyhun ile yapılan 27.03.2020 tarihli görüşme. 


\section{Mustafa Nahit Tunaşar'ın Emeklilik Yaşamı}

Askerî hekimlik görevini tamamladıktan sonra hem iklim olarak beğeneceği hem de yeterli hekim olmayan bir ilçeye yerleşmeye karar verdi. Ailesi ile görüş birliği sağladıktan sonra eski mesai arkadaşlarından Beşir Bey ile beraber İzmir civarındaki ilçeleri dolaştı ve Tire'yi beğendi. En kısa zamanda Tire'de bir muayenehane açarak mesleğini burada sürdürmeye başladı. Tunaşar, maddi durumu kötü, parası olmayan hastalardan muayene ücreti almayan, kendisine gelen ilaçları ihtiyaç sahiplerine ücretsiz veren "paşa doktor", "fakir babası" gibi sevgi ifadeleri ile kucaklanan bir hekim oldu. Muayenehaneye gelemeyecek derecede ağır hasta olanların gece gündüz evlerine gitti. İlçeye yolu olmayan dağ köylerine at sırtında gidip hastalarını muayene etti. Bu davranışları ve kişiliği ile Tire'de kısa sürede sevilen bir kişi olmayı başardı.

Hekim olarak çalışmalarını sürdürmenin yanında çeşitli hayır kurumlarına katkı sağlayan Tunaşar, Tire Çocuk Esirgeme Kurumu ve Kızılay gibi kuruluşların da başkanlı̆̆ını yaptı. Bu kurumların yardımına muhtaç insanların ihtiyaçlarını en iyi şekilde karşılamak üzere İzmir ve genel merkezler nezdinde girişimlerde bulundu. Ülkenin ekonomik durumu çerçevesinde mümkün olan en iyi hizmetleri yerine getirmeye çalıştı. Tire halk1 ile çok sıcak ilişkiler kurması, özellikle muayenehanesine gelen hastalarıyla uzun uzun memleket sorunları tartışması ve siyasi içerikli konuşmalar ortaya çıkması Tunaşar'ın yaşamında yeni bir girişimi tetikledi. Ailesine pek hissettirmemiş olsa da kendince haksız ve zamansız bir şekilde emekli edilmesinin burukluğunu giderecek bir yola yönelerek Demokrat Parti (DP) Tire İlçe Teşkilatı'na katıldı.

İlçe halkı tarafından büyük oranda kabul gören DP'nin hızıı bir genişleme göstererek bir yıl içinde on dört parti ocağı kurulması; 1949 yılı kongresinde ifade edildiği şekilde ilçe teşkilatının üye sayıs1, ilçe nüfusunun \%80'ini oluşturması dikkat çekiciydi. Aynı kongrede Mustafa Nahit Tunaşar, DP İzmir İl Delegesi olarak seçildi. Partinin 1950 yılı kongresi geniş katılımlı olarak 28 Ocak 1950 günü Ankara'da gerçekleştirildi. Genel Başkan Celal Bayar'ın da katıldığı toplantılarda İzmir İl Başkanı Ekrem Hayri Üstündağ CHP'yi eleştiren ve iktidar tarafından kendilerine yapılan suçlamalara cevap veren konuşmalar yaptı. Kongre raporunda İzmir ilinin "Hürriyet ve demokrasinin sarsılmaz ve zapt edilemez bir kal'ası" olduğuna vurgu yapıldı ve Tunaşar, bu kongrede de DP İzmir İ Delegesi olarak seçilenler arasında yer ald.$^{31}$ Siyasi çalışmalarında kendini bir nefer olarak görüp tüm faaliyetlere gönüllü olarak dahil olan Tunaşar, DP’nin muhalefet

31 Aymelek Şenel, Demokrat Parti İzmir İl Örgütü (1946-1960): Muhalefetten İktidara Bir Siyasal Partinin Yerel Politikası, Manisa, Manisa Celal Bayar Üniversitesi Sosyal Bilimler Enstitüsü Tarih Anabilim Dalı, Doktora Tezi, 2018, s. 152, 172. 
partisi olarak varlığını gösterdiği dönemde halkı etkilemek, parti iç birlikteliği kuvvetlendirmek amacıyla yürütülen çalışmaların Tire ve çevresinde gerçekleştirilenlerini koordine etti.

14 Mayıs 1950'de yapılan genel seçimlerde DP halkın büyük ölçüde tercih ettiği, desteklediği bir parti oldu ve iktidara geldi. 1954 seçimlerinde de DP'nin ezici üstünlüğü görüldü. ${ }^{32} 1957$ seçimlerinde oy kaybetmesine rağmen oyların yaklaşık \%48'ini alan DP'nin iktidarı devam etti ancak bu tarihten sonra ülkede huzursuzluklar, sıkıntılar ve gerginlikler artmaya başladı. 27 Mayıs 1960 günü bir grup subay, oluşturdukları Millî Birlik Komitesi (MBK) ile ordu adına yönetime el koyduklarını açıkladılar. ${ }^{33}$ Ülkeye huzur ve güven getirmek üzere gerçekleştirildiği söylenen askerî yönetimin Yassıada'da yürüttüğü yargılamalar sonucu Başbakan Adnan Menderes, Dışişleri Bakanı Fatin Rüştü Zorlu ve Maliye Bakanı Hasan Polatkan idam edildi. ${ }^{34}$ Yaşananlardan ciddi rahatsızlık ve üzüntü duyan Mustafa Nahit Tunaşar, askerî darbeyi hiç benimsemedi ve şiddetle eleştirdi. DP saflarında siyaset yapmasına rağmen Tire'de gerçekleştirilen tutuklama ve gözaltılar sürecinden etkilenmedi, herhangi bir sorgulamaya muhatap olmadı. Kendisi daha sonra resmî bayram ilan edilen 27 Mayıs günlerinde evine bayrak asmamak ve kutlamaları görmemek için Tire'den ayrılıp İzmir'e gitmeyi, ertesi gün geri dönmeyi tercih etti.

Cuntanın emekliye sevk ettiği 11. Genelkurmay Başkanı Emekli Orgeneral Ragıp Gümüşpala başkanlığında, 11 Şubat 1961 günü yeni bir siyasi parti olarak Adalet Partisi (AP) kuruldu. 1961'de yapılan milletvekili ve senato seçimlerine katılan AP, yeni hükümette koalisyon ortağı oldu. Gümüşpala'nın vefatı üzerine genel başkanlığına Süleyman Demirel'in seçilmesinden itibaren etkili bir muhalefet partisi olan AP, 1965 seçimlerinde büyük başarı elde etti ve tek başına iktidar oldu. ${ }^{35}$ AP'nin Tire ilçesi kurucusu olan Tunaşar, siyasi çalışmalarına bu parti çatısında devam etti. İzmir senato aday adayı olarak belirlenen Tunaşar, senatör seçilemedi; ancak Tire ve İzmir'de beğeni ile karşılanan faaliyetlerde yer ald1.

Tire'deki yaşamı boyunca sivil toplum örgütleri ve yardım derneklerinin çalışmalarında hep ön planda olan Tunaşar, Kızılay’da ve Çocuk Esirgeme Kurumu'nda başkanlık yaptı, İzmir ili ve genel merkezler seviyesindeki toplantılarda örnek görüşler sunarak

32 Şerafettin Turan, Türk Devrim Tarihi, 4. Kitap, Ankara, Bilgi Yayınevi, 1999, s. 11, 88.

33 Cezmi Eraslan, “Atatürk’ten Sonra Türkiye'nin İç Politikası”, Türkiye Cumhuriyeti Tarihi -II-, ed. Durmuş Yalçın vd., Ankara, Atatürk Araştırma Merkezi Yayını, 2008, s. 576.

34 Feroz Ahmad, Demokrasi Sürecinde Türkiye (1945-1980), çev. Ahmet Fethi, İstanbul, Hil Yayınları, 2007, s. 220.

35 Cezmi Eraslan, “Atatürk’ten Sonra...”, s. 579, 585. 
takdir kazand1. Siyasi düşüncesi ve sosyal durumu ne olursa olsun vatandaşlar arasında hiçbir ayrım gözetmeksizin çalışmalar yapmaya özen gösterdi. Babasının bulunduğu çevrede her zaman sevilen, sayılan ve sözü dinlenen bir kişi olduğunu vurgulayan Aysel Ceyhun, onun yüksek sesle güldüğünü pek gören olmadığını, sigara ve kahve tiryakisi olduğunu, eve mutlaka bir gazete ve mesleki gelişmeleri takip etmek için Dirim Tip Dergisi alındığını belirtti. Huzurlu bir aile ortamını sağlamış, çocuklarının en iyi şekilde yetişmesi için gayret göstermiş bir aile reisi olan Mustafa Nahit Tunaşar, 24 Kasım 1970 günü vefat etti. Askerî törenle kaldırılan cenaze kortejinde büyük torunu Ersel Ceyhun, İstiklal Madalyası'nı taşıdı. ${ }^{36}$ Tire İlçe Mezarlığg'na defnedilen Tunaşar'ın Tirelilere yaptığı hizmetleri unutmayan ilçe halkı, ilçe merkezindeki bir caddeye "General Nahit Tunaşar Caddesi” adını verdi.

\section{Türk Ocakları ve Mustafa Nahit Tunaşar}

Türk Ocakları, Osmanlı Devleti’nin çöküş içinde bulunduğu yıllarda Türklük bilincinin ve Türk varlığının sona ermek üzere olduğu düşüncesine ve endişesine sahip vatanseverlerin çalışmaları sonucu kuruldu. Askerî tıbbiyeli gençlerin başlattığı bir düşünce hareketi, ilerleyen günlerde Türk aydınlar grubunun devreye girmesiyle olgunlaşarak yeni bir dernek kurulması çalışmalarıyla fiili olarak 20 Haziran 1911'de hayata geçirildi. Genel esasların ve programın belirlenmesi için yapılan toplantılara tıbbiyeliler adına katılan Doktor Fuat Sabit'in (Ağacık) teklifi ile kurulan derneğe Türk Ocağı adı verildi ve resmî kuruluşu 25 Mart 1912 olarak kayda geçti. İlk tüzükte ocağın amac1 "Türklerin milli terbiye ve ilmi, içtimai, iktisadi seviyelerinin terakki ve ilasıla Türk ırk ve dilinin kemaline çalışmak" şeklinde belirlendi. ${ }^{37}$ Sadece millî ve toplumsal bir dernek olarak kalması, kesinlikle siyasetle uğraşmamak ve siyasi partilerle ilişkili olmamak ilkesi vurguland1.

Türk Ocaklarının kuruluş sürecini bir askerî tıbbiyeli olarak yaşayan Mustafa Nahit Bey, ocak ile irtibatını sürdürdü, her firsatta görüş ve düşüncelerini ocak mensuplarına aktarmayı hedefledi. Türk milliyetçiliği, Türk dili gibi temel konuların vatandaşlara aktarılması konusunda dersler, konferanslar, gösteriler düzenlenmesi; okullar açılması, kitap ve dergiler yayımlanması amacını sürdüren ocak çalışmalarını her firsatta destekledi. Kırklareli’nde bulunduğu yıllarda da özel günlerde konferans vermek ve çeşitli toplantılar düzenlemek faaliyetlerini zevkle yürüttü.

36 Aysel Ceyhun ile yapılan 27.03.2020 tarihli görüşme.

37 Yusuf Sarınay, “Türk Ocaklarının Kuruluşu ve Misyonu”, Türk Yurdu, C.32, S.295, 2012, s. 25; Necmeddin Sefercioğlu, “Türkiye'nin En Eski ve En Büyük Sivil Toplum Kuruluşu Türk Ocağı”, 30 Kasım 2001 (Çevrimiçi), https://www. turkocaklari.org.tr/turk-ocagi-tarihi/turk-ocaklarinin-kisa-tarihcesi-3496, 23 Haziran 2020. 


\subsection{Türk Ocakları Konferansı}

Türk Ocaklarının kuruluş yıldönümü münasebetiyle 1931 yılında Kırklareli Türk Ocağı'ndaki konferansına dönemsel gelişmeler nedeniyle önemli konu başlıkları belirledi. Menemen Olayı'nın üzerinden kısa bir süre geçmiş olması ve ülkede olağanüstü gelişmeler yaşanması nedeniyle konuşma içeriğini Türklük, milliyetçilik ve kısmen İslami dönemi eleştiren değerlendirmelerle hazırladı. Ayrıntılı ve uzun dönemi kapsayan görüşlerini genel olarak şu şekilde aktarmak mümkündür: ${ }^{38}$

Tunaşar'ın ilk eleştirisi, eserlerinde genellikle "Etrak-i bî idrak-akılsız Türkler" şeklinde küçümseme ifadesi kullanmış olan Osmanlı dönemi tarih yazıcılarına yöneliktir. Devleti yöneten padişahların da Türk olmalarına rağmen bu hakaretten kendilerine pay çıkarmamalarını, cehaletlerine ve sahip oldukları zevk ve sefa dolu yaşamlarını sürdürmek istemelerine bağlamıştır.

Türklüğün ilerlemesi ve yükselmesi yolunda çalışmalar yapan saltanat üyeleri hakkında bilgi aktarırken, Sultan II. Mahmut'un annesi Nakşidil Sultan'ın (Aimêe) ${ }^{39}$ girişimlerinden övgüyle bahseden Tunaşar, onu Fransızlığını unutmuş ve kendini tamamen Türklüğün ilerlemesine adamış bir padişah eşi ve annesi olarak değerlendirmiştir. Ona göre Nakşidil Sultan, Türklerin en büyük kusurunun bağnazlık ve körü körüne inanış olduğunu düşünmüştür. Son üç asırda tahta çıkan tüm padişahların kukla gibi olduğunu iddia eden Tunaşar, annesine çok büyük hürmeti olan ve onun bir sözünü iki etmeyen Sultan II. Mahmut'un da farklı yapıda olmadığını belirtmiştir. Buna rağmen onun döneminde hayata geçirilen uygulamaların kendinden öncekiler gibi Türklüğe zarar vermediğini, tam tersine yükseliş yolunu açan kararlar olduğunu savunmuştur. Bu konuda dinleyicilerine aktardığ 1 örnek fesin kullanımıdır. Püskülü küçültülmüş bir çeşit Yunan başlığı olarak gördüğü fesin kabul edilmesinin, halkın bir kısmı tarafından dinden çıkma uygulaması olarak görüldüğünü ve bu konuda tüm ülkeye dedikodu yayıldığını bildiren Tunaşar, bu dedikodunun kaynağını ulema takımı ile Türk olmayan ve gayrimüslim unsurlar olarak belirtmiş̧ir. Tunaşar'ın aktarımlarında gerçek Türkler, vatanını seven ve sorumluluklarını idrak eden kişilerdir. Bunlar ülkenin huzurunu bozacak

38 Tunaşar'ın Türk Ocağı konferansı için hazırladığı ve daktilo ile yazdığı 12 maddelik kişisel çalışmasından özetlenmiştir.

39 Tunaşar'ın “Aimêe (Aimêe du Buc de Rivery)” olarak aktardığı Nakşidil Sultan'ın kökeni hakkında değişik görüşler mevcuttur. Zengin bir Fransız olduğu ve Cezayirli korsanlar tarafından kaçırılıp padişaha hediye olarak İstanbul'a gönderildiği, zekâsı ve güzelliği ile ön plana çıkıp zamanla padişah I. Abdülhamit'in eşi olduğunu kabul eden görüşler yanında; Kafkas kökenli olduğu ve Aimêe adının diplomatik ve roman unsuru ön plana çıkmış yanlış bir aktarım olarak kullanıldığını savunan görüşler de vardır. Fikret Sarıcaoğlu, "Nakşidil Sultan", Türkiye Diyanet Vakfi İslâm Ansiklopedisi (DİA), C.32, 2006, s. 343; Handan Koçyiğit, "Nakşidil Valide Sultanın İstanbul'daki Üç Müstakil Çeşmesi”, Social Sciences Studies Journal, C.5, S.33, 2019, s. 2023. 
konuları desteklemezler. Ne var ki bu gruptakilerin bazıları kuvvetli dindar olmaları nedeniyle din adamlarının dediklerine inandıklarından, onların din perdesi altındaki yalanlarına ve telkinlerine alet olmuşlardır.

Tunaşar'a göre Batı'daki tıp okullarına benzer bir tıp fakültesinin açılışına da Nakşidil Sultan vesile olmuştur. Hastalığı döneminde bitkilerle tedavi yöntemi uygulayan hekimleri reddetmesi, İstanbul'da hekimlik yapan yabancılara da güvenmemesi nedeniyle Osmanlı Devleti'nde tıp eğitimi için ilk adımların atılmasına neden olmuştur. Galatasaray'da bulunan Enderun Mektebi'nin boşaltılarak askerî tıp fakültesi olarak eğitime başladığını anlatan Tunaşar, o dönemin koşulları gereği Türkçe eğitim yapılamamasını üzüntüyle ifade etmiştir. Bu konudaki açıklamalarının ve kısa bir tarihçe sunmasının asıl nedeninin, İslam tarihçiliğinin ortadan kaldırdığı Türk milliyetçiliği aşkının “Küçük Asya ve Balkan Yarımadasındaki Türkler" tarafından bu okulun sıralarında yeniden alevlendiğini hatırlatmak olduğunu belirtmiştir.

Türk çocuklarının eğitiminin yabancılardan geri kalmasından ve çağdaş gelişmelere uzak kalınmasından duyduğu üzüntüyü dile getiren Tunaşar, bir yabancı dilin öğrenilmesi gereğini anımsatmak üzere ülkedeki görüntüyü ve kendi okulunda sayıca fazla olan Hristiyan öğrencilerin durumunu sebep-sonuç ilişkisi çerçevesinde şu ifadelerle anlatmaya çalışmıştır: “...Bu ne koyu yobazlık, bu ne kokmuş zihniyetti! Aziz kardeşlerim; topră̆ımızı kemiren bu zihniyetler çok eski değil, bırakın Anadolu'nun ücra köşelerini, İstanbul'da bile bütün kuvvetiyle yönetime hakimdi. Bu nedenle okulun yarıs Hiristiyan ögrencilerle doldu. Bu devletin yetiştirdiği özellikle Sirp, Bulgar öğrenciler, Fransızca bilmenin bir sonucu olarak Fransız Devriminin derinliklerini ögrendiler ve kendi millî duyguları alevlendi. Bu nankörlerin hemen hepsi mezun olduktan sonra ordumuzda hizmet etmediler, memleketlerine firar ettiler veya memleketlerine komşu diğer yabancı ülkelere sığındılar”. Yabancı bir dil öğrenmenin dinden çıkma olarak kabul edildiğini anlatan Tunaşar, bir evin içine yabancı dille yazılmış kitap sokmanın günah, böyle kitap ve hatta fotoğraf bulunan odada namaz kılmanın bile haram olarak algılandığı bir toplumda, okulun eğitim dilinin Fransızca olması nedeniyle ailelerin çocuklarını okula göndermediğini dolayısıyla kadroların gayrimüslimler tarafından doldurulduğunu belirtmiştir.

Konuşmasının bir bölümünde, Mekteb-i Tıbbiye'de doğan millî ve vatani duyguların zamanla kendi saltanatlarına zarar vereceğini düşünen padişahların okuldaki bu oluşuma şiddetle engel olduklarını belirten Tunaşar, özellikle II. Abdülhamit döneminde bu "gizli” teşkilatlanmanın acımasızca cezalandırıldığını, bazı öğrencilerin gemilerle 
Trablusgarp'a ve oradan da Fizan çöllerine sürüldüğünü, bazılarının da ortadan kaldırıldığını anlatmıştır. Vatan sözcüğünün kullanılmasının bile yasaklandığı günlerde gençlerin sahip olduğu ruhun söndürülemediğini özellikle vurgulamıştır.

Tunaşar'ın 1srarla vurguladığı konulardan biri de Türklük karşıtı eylemler ve Türklüğe zarar veren söylemler olmuştur. Meşrutiyet'in ilanı süreci hakkında düşüncelerini açıklarken yaşanan olumlu havanın bir müddet sonra Türklük karşıtlığına dönüştüğünü belirterek eşitlik ve kardeşlik gibi kulağa hoş gelen kavramların özellikle gayrimüslim unsurları yatıştırdığını ancak bir iki sene sonra Türklüğe saldırıların tekrar başladığını aktarmıştır. “...Mebusan Meclisinde Arap mebuslar Araplıktan, Arnavut mebuslar Arnavutlardan dem vurmă̆a başladı. Meşhur Rum mebus Boşo Efendi, büyük bir cesaretle kendisinin 'Osmanlı Bankası kadar Osmanlı' olduğunu söylüyordu” açıklamaları ile Hristiyan unsurlar yanında Müslüman unsurlardan da zamanla Türklük karşıtı eylemlerin başladığını ifade etmiştir.

Konuşmasında Türk Ocaklarının kuruluş sürecini anlatırken tıbbiyelilerin öğrencilik sıralarında başlattıkları dergi çıkarma konusuna anlatan Tunaşar, 1910 yılı başlarında yayımlanmaya başlayan Türk Yurdu isimli derginin önemine değinmiştir. "...Türkün mübarek kanıyla yoğurulan bu aziz toprakların hakiki adı ilk olarak kemali serbesti ile bu risalenin adına kondu. Bütün Türk tıbbiyeliler bu gazeteye abone oldular” ifadeleriyle derginin özelliğini aktarmıştır. Ne var ki Türk milliyetçiliğinin güçlenmesi adına bu derginin yayımlanmasını yetersiz bulan tıbbiyelilerin tüm ülkeye yayılacak bir oluşuma karar verdiğini, oluşturulacak yeni örgütün adı üzerine uzun tartışmalar yaşandığını ve sonunda Türklerin gururla bir araya geldiği Türk Ocaklarının kurulduğunu etkileyici bir şekilde anlatmıştır.

Konuşmasının sonlarına doğru Osmanlı Devleti'nin son dönemlerinde yaşanan savaşlardan ve Hristiyan unsurların dışarıdan aldıkları yardım ve koruma sayesinde yaptıklarından bahseden Tunaşar, bu arada Türk olmayan Müslüman topluluklarının isyanlarını ve Türklere yaptıklarını gündeme getirmiştir. Ona göre Türkler, Balkan Savaşlarında Hristiyan unsurlarla iş birliği yaptığını düşündüğü Arnavutlarca arkadan vurulmuş; Araplar ise Yemen, Necit vb. bölgelerde Türklere isyan etmişlerdir. Bu bağlamda din birliğini boş bir hayal olarak görmüş, Türk'e sadece Türk’ün yardım edeceğini öngöremeyen padişahın, Birinci Dünya Savaşı başladığında kutsal Sancak-ı Şerif’i çıkararak tüm Müslümanları düşmana karşı birlikte olmaya davet ettiğinde başarısız olduğunu anımsatarak aktarmıştır. Müslümanların "ihaneti” olarak aktardığı olaylara örnek olarak; din sancağına en fazla saygı göstermesi gerektiğini düşündüğü Arapların, 
Rus cephesi karşısındaki ordu gerisine taarruz etmeğe kalkışan Ermeniler gibi Sina' daki Türk birliklerinin gerisini vurmak istemesini göstermiştir.

İslamcılık ve İslam birliği siyasetinin geçerliliğini kaybettiği düşünen Tunaşar, dinleyicilere şu olayı anlatmıştır: “...Ingilizler tarafindan bir ödül olarak Irak Emiri tayin edilen Faysal, Arap süvarisiyle ve Ingilizlerle beraber ordumuzu takip ve ele geçirdikleri Türk askerini imha ederek Şam'a girdikte, bir Arabın bir tek kelime Türkçe söylediğini işitmiş ve bunun üzerine orada bulunan halka hitaben söylemiştir ki; 'Şimdi yolda Türkçe görüşen on bir Türk neferini kestim. Bundan sonra her kim Türkçe görüşürse onun da dilini keseceğim'. Işste Emir Faysal bütün İslam cihanına ilan etmiştir ki Islamlık siyaseti iflas etti. Onun yerine milliyet siyaseti kaim oldu’.

Tunaşar'a göre ülkede Türk devrimini hazmedememiş ve eski zihniyeti yaşatmak düşüncesinde olan çok sayıda insan vardı. Türk vatandaşlarının bu tehlikeyi göz ardı etmemesini ve uyanık bulunmasını tavsiye eden Tunaşar, rejime sahip olunmasını ve bu konuda herkesin kıskanç davranmasını istemiştir. Her zaman tetikte bulunulması gerektiği vurgulayarak Millî Mücadele'nin başlangıcından itibaren yaşanmış olaylardan ve Türk milletine zarar verdiğini düşündüğü kişilerden örnekler vermiştir. Türkiye Cumhuriyeti’nin kurucusu hakkındaki görüş ve düşüncelerini de aktaran Tunaşar, Gazi’nin gerçekleri bildiğini ve ulus menfaatlerinin nerede olduğunu tespit etmekte son derece isabetli kararlar aldığını defalarca gösterdiğini söylemiştir. Her Türk vatandaşının Gazi’ye ve devrimlerine sahip çıkması gerektiğini hatırlatarak Türk Ocakları Genel Başkanı Hamdullah Suphi Bey'in açıklamalarına atfen, benliğini idrak eden ve aydınlanmış olan bir Türk'ün gerçek anlamda misyoner gibi davranması gereğini vurgulamıştır.

\subsection{Türk Ocaklarının Kapatılma Süreci ve Tunaşar'ın Kapatılmaya İtiraz Mektubu}

Türk Ocakları, çalışmalarına başladığı II. Meşrutiyet günlerinden itibaren “Türklük” ve "Türk Milliyetçiliği”’ konularında en uzun süre hizmet vermiş ve ülkenin en köklü sivil toplum örgütü olarak bilinen bir yapılanmadır. Kuruluşundan itibaren çeşitli alanlarda etkinliklerde bulunan ocak şubeleri, 1930'lu yıllarda spor ve müzik alanlarındaki çalışmalarıyla dikkat çekmişti. Ocakların 42 şubesinde müzik kolu, 44 şubesinde spor teşkilatı vardı. İzcilik, müzik, spor (atıcılık, basketbol, binicilik, futbol, güreş, su sporları ve voleybol) çalışmalarını başarıyla yürüten şubelerin kültürel etkinlikleri de ön plana çıkmıştı. 40.000 ciltlik bir ihtisas kütüphanesine sahip olan merkez kütüphanesi ile örnek bir okul haline gelmişti. ${ }^{40}$

40 Nermin Kılıç, Atatürk'ün Türk Ocaklarındaki Konuşmaları, Bolu, Abant İzzet Baysal Üniversitesi Sosyal Bilimler Enstitüsü Tarih Anabilim Dalı, Yüksek Lisans Tezi, 2006, s. 48. 
Yurt gezileri esnasında Cumhurbaşkanı Mustafa Kemal'in de ziyaret edip çalışmalarıyla yakından ilgilendiği ve beğenilerini ilettiği ocak şubeleri, devletin temel rejimini halka aktarma çalışmalarını sadece teorik bilgilerle yapmıyordu. Modernleşme ve çağdaşlaşma yolundaki uygulamaları ile örnek olmaya çalışıyordu. Kadınların sosyal yaşamdaki yerini kuvvetlendirmesini ve eşit vatandaş olarak toplumda söz sahibi olabilmesini sağlayıcı uygulamalar dikkat çekici boyutlardaydı. Kadınların konuşmacı olarak yer aldığı konferans ve bilimsel etkinlikler yanında sanatsal faaliyetlerde de erkeklerle aynı yerde bulunmasına önem verilmekteydi. ${ }^{41}$ Doğal olarak kadın ve erkeklerin aynı ortamda birlikte olması, kadınların tiyatro oyunlarında sahnede yer almasından ciddi derecede rahatsızlık duyan ve bu gelişmeleri şiddetle protesto eden kesimler vardı. Tüm olumsuzluklara rağmen ocakların eğitim ve öğretim uygulamaları başarıyla sürdürüldü.

Türk Ocaklarında görülen farklı bir uygulama da kişilere soyadı verilmesi oldu. Soyadı Kanunu kabul edilmeden önce soyadının ilk defa Türk Ocaklarında kullanılması da önemli bir ayrıntıydı. Türk Ocakları Başkanı Hamdullah Suphi (Tanrıöver) Bey’in ocaktaki soyadı “Özkul”, ocağın bir üyesi olan İsmet (İnönü) Paşa'nın soyadı ise "İnan” olarak belirlenmişti. ${ }^{42}$ Çağdaş bir ülke olma, demokratik bir düzen kurma ve çok partili siyasi hayata geçme arzusundaki Türkiye Cumhuriyeti’nin sıkıntılı günler yaşadı̆̆ı dönemlerde Türk Ocakları, devletini destekleyen bir dernek görünümü sergiledi. Genç Cumhuriyet' in temellerini güçlendirme çalışmalarına katkı sağlama girişimlerinin yürütüldüğü yıllarda yaşanan üzücü ve tehlikeli bir olay, Türk Ocakları tarafından da dikkatle izlendi ve şiddetle tepki gösterildi. 23 Aralık 1930 günü Menemen'de yaşanan ve tüm ülkeyi etkileyen gerici ayaklanma olayını kınamak üzere 2 Ocak 1931 günü genel merkezde bir toplantı düzenledi. Günün anlam ve önemine yönelik çeşitli konuşmalardan sonra Türk Ocakları Başkanı Hamdullah Suphi Bey de bir konuşma yaptı. Konuşmasında yeni bir düzene karşı girişilen bu eylemi kınadıklarını, yurdun her köşesine yayılmış ocak şubeleriyle Türk İnkılabı'nı savunmaya hazır olduklarını açıkladı.

Cumhurbaşkanı Mustafa Kemal, Menemen’de yaşanan ve birkaç kişinin gerçekleştirdiği irtica eyleminden öte bölge halkının böyle bir eyleme gereken karşılığı vermemesi ve hatta az sayıda da olsa destek vermesinden çok rahatsız oldu. "...Bu ne haldir, mürteciler hükümet meydanında ordunun subayını din adına boğazlayabiliyorlar. Binlerce Menemenliden kimse çıkıp mâni olmuyor, bilakis tekbirlerle teşvik ediyorlar. Yunan idaresi altındayken bu hainler neredeydiler? Onların namusunu ve dinini kurtaran ordunun bir subayına reva gördükleri bu saldırının cezasını yalnız hain katiller

41 Tezer Taşkıran, Women In Turkey, İstanbul, Redhouse Yayınevi, 1976, s. 44.

42 Halim Serarslan, Hamdullah Subhi Tanrı̈̈ver, Ankara, Türk Kültürünü Araştırma Enstitüsü Yayını, 1995, s. 49. 
değil, hepsi en ă̆ır şekilde çekmelidir. Bu Cumhuriyet'i ve bizim başımızı kesmektir. Bundan bütün Menemen sorumludur. Bu kasaba 'Vilmodit' ilan edilmeye müstahak olmuştur"43 sözleriyle tepkisini en sert şekilde dile getirdi. Türk siyasi tarihinin önemli kırılma zamanlarından biri olan Menemen Olayı sonrasında yapılan düzenlemeler Türk Ocaklarını da olumsuz etkiledi. Zaten değişik zamanlarda tartışmaya neden olan bazı olaylar (1rkçı düşüncelerin ön plana çıkması, muhalif Serbest Cumhuriyet Partisi'ni destekleme, kuruluş amaçları dişında çok farklı alanlarda etkinlikler düzenleyerek güçlenme, Turancı görüşler nedeniyle Sovyet Rusya tarafından şikâyet edilme, zamanla güçlenerek iktidar partisinin yerine geçme endişesi vb.) ve cumhurbaşkanının bizzat tespitleri, bu oluşum hakkında yeni bir karar alınacağının işaretlerini veriyordu.

22 Mart 1931 günü Türk Ocakları İlim ve Sanat Heyeti Üyesi Afyonkarahisar Milletvekili Ruşen Eşref (Ünaydın) Bey ile görüşen Cumhurbaşkanı Mustafa Kemal: “...Kuruluş tarihinden beri bilimsel alanda halkçılık ve milliyetçilik ilkelerini yaymaya ve duyurmaya bağlılıkla ve imanla çalışan ve bu yolda memnunluğu gerektiren hizmetleri geçmiş olan Türk Ocakları'nın, aynı esasları siyasal alanda ve uygulamam alanında gerçekleştiren partimle bütün anlamıyla birlik olarak çalışmalarını uygun gördüm. Bu kararım ise, millî kuruluş hakkında duyduğum itimat ve güvenin ifadesidir. Aynı cinsten olan kuvvetler, ortak amaç yolunda birleşmelidir"44 sözleriyle Türk Ocaklarının kapatılacağı konusundaki kararını iletti. Bu açıklamanın gazetelerde yayımlanmasından itibaren olumlu ve olumsuz değerlendirmeler yapıldı. Türk Ocakları üyelerinin büyük çoğunluğu tarafından üzüntü ve endişe ile karşılanan bu karara değişik yollardan tepkiler verildi. $\mathrm{Bu}$ üyelerden biri olan Mustafa Nahit Bey, Kırklareli'nden yazdı̆̆ “Ocă̆ımızı söndürmeyiniz” başlıklı mektubuyla geçmişte ve halen ocak bünyesindeki faaliyetlerini ve konu hakkındaki düşüncelerini, tekliflerini açık olarak iletti. ${ }^{45}$ Sorumlu bir Türk vatandaşı kimliği ile kaleme aldığı samimi duygularını derneğin en yetkili makam olan Türk Ocakları Başkanı Hamdullah Suphi Bey’e aktard1. Ne var ki 10 Nisan 1931 tarihli olağanüstü kurultayda Türk Ocaklarının kapatılmasına ve derneğin sahip olduğu tüm varlıkların ve hakların Cumhuriyet Halk Fırkası'na devredilmesi kararlaştırıldı. Türk Ocaklarına sahip çıkmak isteyenler, devletin en üst kademesinin bu kararını sessizce kabullenmek zorunda kaldilar.

43 Fransızca bir sözcük olan "Ville Maudite (vilmodit)” cezalandırılmış şehir anlamındadır. Bütün halkın şehir dışına çıkarılıp, ailelerin başka şehirlerine dağıtılmasından sonra boşaltılmış şehrin tümüyle yakılmasını ifade eder. Necdet Aysal, "Yönetsel Alanda Değişimler ve Devrim Hareketlerine Karşı Gerici Tepkiler Serbest Cumhuriyet Fırkası Menemen Olayı”, Ankara Üniversitesi Türk Inkılap Tarihi Enstitüsü Atatürk Yolu Dergisi, S.44, 2009, s. 611.

Utkan Kocatürk, Atatürk'ün Fikir ve Düşünceleri, 3. bs., Ankara, Atatürk Araştırma Merkezi Yayını, 2007, s. 307.

Ek-3: Mustafa Nahit Tunaşar'ın Hamdullah Suphi Bey'e Mektubu. 


\section{Sonuç}

İnsanlığa ve devletine katkı sağlayan, kişilerin kendileri ve ailelerinin ihtiyaçlarını karşılayabilmek için yasalara uygun şekilde yürüttükleri her meslek kutsaldır. Bazı dönemlerde yaşanan toplumsal gelişmeler nedeniyle önemi daha fazla hissedilen hekimlik (tabiplik, tıp doktorluğu) mesleğinin mensupları, kutsal çalışmalarının yanında Türkiye Cumhuriyeti'nin kuruluş sürecinde olduğu gibi, çağdaş bir ülke haline getirilmesinde ve siyasal hareketlerde önemli rol oynamışlardır. Meslek yaşamı boyunca genel sağlık hizmetleri yanında salgın hastalıklarla da mücadele ederek vazife yapmış askerî hekimlerden biri olan Mustafa Nahit Tunaşar, diğer meslektaşları gibi bu ülkeye değişik alanlarda da hizmet etmiş bir Türk aydınıdır. ${ }^{46}$

Bulgaristan'dan Anadolu'ya göç etmek zorunda kalmış bir ailenin çocuğu olarak doğan Mustafa Nahit Tunaşar, 1908 yılında İstanbul Tip Fakültesi'ne askerî öğrenci olarak kaydolmuştur. Ülkenin içinde bulunduğu zor y1llarda devletin kurtuluşuna katkı sağlayacak girişimlerde bulunan ve Türklük bilincinin yaşatılması için arayış içinde olan tıbbiyelilerden biri olarak mücadele etmiş, öğrenciliği esnasında Balkan Savaşı'nın başlaması nedeniyle arkadaşlarıyla beraber eğitimine ara verip cepheye katılmıştır. Daha sonra yüzbaşı rütbesi ile mezun olup Birinci Dünya Savaşı süresince Doğu (Kafkas) Cephesi'nde görev yapmış, bu bölgedeki hizmet süresini tamamlayıp İstanbul'a atanmıştır. Savaş sonrası çeşitli birlik ve hastanelerde görev yapan Tunaşar, Kırklareli'nde görev yaparken 1929 yılında Selanik göçmeni bir ailenin kızı olan Nadire Kerim Hanım ile evlenmiş ve biri kız biri erkek iki çocuk babası olmuştur.

Genç Türkiye Cumhuriyeti'nin vatandaşlarının aydınlatılması ve yeni rejimi sahiplenmeleri için eğitilmelerinin kaçınılmaz olduğunu belirten Tunaşar, bu vazifenin öncelikle devlet daireleri memurlarının, öğretmenlerin ve aydınların omuzlarında olduğunu vurgulamıştrr. Bu bağlamda sadece mesleğin yerine getirilmesini yeterli görmemiş, devrime ilgisiz kalan, halk arasına girdiğinde ve görevi gereği köylülerle temas ettiğinde devrimin ilke ve özelliklerini anlatmayan devlet görevlisinin vazifesini yapmış sayılmayacağını savunmuștur.

1947 yılında emekliye sevk edildikten sonra serbest hekimlik yapmak üzere yerleştiği Tire'de halkın sevgi ve saygısını kazanan Tunaşar, bir hekim olarak mesleğini sürdürmenin yanında hayır işlerini yürütmüş; Kızılay'da ve Çocuk Esirgeme Kurumu'nda yöneticilik yapmıştır. Önce Demokrat Parti daha sonra da Adalet Partisi’nin bir üyesi olarak siyasi çalışmalarda da bulunmuştur. Genel olarak siyasetten beklentilerini elde

46 Ek-4: Mustafa Nahit Tunaşar'ın Fotoğraf Albümünden. 
ettiğini çevresine memnuniyetle anlatan Mustafa Nahit Tunaşar, 24 Kasım 1970 günü hayata veda etmiştir. Tire halkının büyük katılım gösterdiği cenazesi askerî törenle kaldırılarak Tire İlçe Mezarlığı'na defnedilmiştir. Askerî hekim olarak Balkan, Birinci Dünya ve Kurtuluş savaşlarına katılmış, başarılarından dolayı çeşitli madalyalarla ödüllendirilmiş olan Mustafa Nahit Tunaşar, değerli bir hekim ve iyi bir aile reisi olmanın yanında Türklüğün yaşatılması ve Türkiye Cumhuriyeti'nin temel değerlerinin korunması için çalışmalar yapmış örnek bir vatandaş olarak anılardaki yerini almıştır.

Hakem Değerlendirmesi: Dış bağımsız.

Çıkar Çatışması: Yazar çıkar çatışması bildirmemiştir.

Finansal Destek: Yazar bu çalışma için finansal destek almadığını beyan etmiştir.

Peer-review: Externally peer-reviewed.

Conflict of Interest: The author has no conflict of interest to declare.

Grant Support: The author declared that this study has received no financial support.

\section{KAYNAKÇA}

\section{Arşiv Kaynakları}

Mustafa Nahit Tunaşar Kişisel Arşivi.

Tunaşar Ailesi Nüfus Kayıt Örneği, 07.03.1995.

\section{Resmî Yayınlar ${ }^{47}$}

\section{Resmî Gazete}

\section{Araştırma Eserler}

Acar, İsmail: “1912’den 2012’ye Türk Ocakları, Tarihi-Çalışmaları-Görüşleri”, Türk Yurdu, C.32, S.295, 2012, s. 100-124.

Ahmad, Feroz: Demokrasi Sürecinde Türkiye (1945-1980), çev. Ahmet Fethi, İstanbul, Hil Yayınları, 2007.

Armaoğlu, Fahir: 20. Yüzyıl Siyasi Tarihi, 1914-1918, Ankara, Türkiye İş Bankası Yayın1, 1983.

Aysal, Necdet: "Yönetsel Alanda Değişimler ve Devrim Hareketlerine Karşı Gerici Tepkiler Serbest Cumhuriyet Fırkası - Menemen Olayı", Ankara Üniversitesi Türk Inkılap Tarihi Enstitüsü Atatürk Yolu Dergisi, S.44, 2009, s. 581-625. 
Baz, İbrahim: “Osmanlı'dan Cumhuriyet'e Norşin Dergâhı ve Şeyh Abdurrahman-1 Taği”, Tasavvuf İlmî ve Akademik Araştırma Dergisi, C.34, S.2, 2018, s. 73-108.

Çakın, Naci: "Redif Teşkilatı", Askerî Tarih Bülteni, S.26, 1989. s. 31-56.

Demirhan Erdemir, Ayşegül: Tıp Tarihi, İstanbul, Nobel Tıp Kitabevi, 2014.

Eraslan, Cezmi: “Atatürk’ten Sonra Türkiye'nin İç Politikası”, Türkiye Cumhuriyeti

Tarihi -II-, ed. Durmuş Yalçın vd., Ankara, Atatürk Araştırma Merkezi Yayını, 2008.

Genelkurmay ATASE Başkanlığı: Birinci Dünya Harbi’nde Türk Harbi, Kafkas (Doğu)

Cephesi, 3. Ordu Harekâtı, Ankara, Genelkurmay Basımevi, 1978.

Genelkurmay Başkanlığı: Türk Silahlı Kuvvetleri Tarihi, Birinci Dünya Harbi, İdari

Faaliyetler ve Lojistik, C.IX, Ankara, Genelkurmay Yayını, 1985.

İçişleri Bakanlığı İller İdaresi Genel Müdürlüğü: Köylerimiz, Ankara, Başbakanlık Basimevi, 1968.

Index-catalogue of the Library of the Surgeon General's Office, United States Army, V.XI, Washington, Government Printing Office, 1955.

Karal, Enver Ziya: Büyük Osmanlı Tarihi, C.IV, Ankara, Türk Tarih Kurumu Yayını, 2001.

Kılıç, Nermin: Atatürk’ün Türk Ocaklarındaki Konuşmaları, Bolu, Abant İzzet Baysal Üniversitesi Sosyal Bilimler Enstitüsü, Yüksek Lisans Tezi, 2006.

Kocatürk, Utkan: Atatürk’ün Fikir ve Düşünceleri, 3. bs., Ankara, Atatürk Araştırma Merkezi Yayını, 2007.

Koçyiğit, Handan: "Nakşidil Valide Sultanın İstanbul'daki Üç Müstakil Çeşmesi”, Social Sciences Studies Journal, C.5, S.33, 2019, s. 2023-2035.

Metin, Barış: Birinci Dünya Savaşı 'nda İran Coğrafyasında Etnik, Dini ve Siyasi Nüfuz Mücadeleleri, Ankara, Berikan Yayınevi, 2012.

Ortaylı, İlber: Osmanlı'ya Bakmak, Osmanlı Çağdaşlaşması, İstanbul, İnkılâp Yayınları, 2016.

Öner, Can: “Tıpta Uzmanlık Mevzuatında Aile Hekimliği Uzmanlığının Evrimi”, Türkiye Aile Hekimliği Dergisi, C.19, S.4, 2015, s. 165-169.

Özdemir, Biltekin: Osmanlı Devleti Dış Borçları, 2. bs., Ankara, Maliye Bakanlığı Yayın1, 2010.

Özdemir, Hikmet: Salgın Hastalıklardan Ölümler, 1914-1918, Ankara, Türk Tarih Kurumu Yayın1, 2005.

Pehlivanlı, Hamit: "Son Dönem Tarih Araştırmalarında Askerî Gazete ve Süreli Yayınların Yeri”, Atatürk Araştırma Merkezi Dergisi, C.XXI, S.61, 2005, s. 243-258. Sarıcaoğlu, Fikret: "Nakşidil Sultan”, Türkiye Diyanet Vakfi İslâm Ansiklopedisi (DİA), C.32, 2006, s. 343-344. 
Sarınay, Yusuf: “Türk Ocaklarının Kuruluşu ve Misyonu”, Türk Yurdu, C.32, S.295, 2010, s. 24-26.

Serarslan, Halim: Hamdullah Subhi Tanriöver, Ankara, Türk Kültürünü Araştırma Enstitüsü Yayını, 1995.

Şenel, Aymelek: Demokrat Parti İzmir Il Örgütü (1946-1960): Muhalefetten İktidara Bir

Siyasal Partinin Yerel Politikast, Manisa, Manisa Celal Bayar Üniversitesi Sosyal

Bilimler Enstitüsü Tarih Anabilim Dalı, Doktora Tezi, 2018.

Taşkıran, Tezer: Women In Turkey, İstanbul, Redhouse Yayınevi, 1976.

Tunç, Bilal-Özçelik, Fatih: “Cumhuriyet Döneminde Ağrı Nüfusundaki Gelişmeler (1927-1980)", Insan ve Toplum Bilimleri Araştırmaları Dergisi, C.6, S.3, 2017, s. 2132-2149.

Turan, Şerafettin: Türk Devrim Tarihi, 4. Kitap, Ankara, Bilgi Yayınevi, 1999.

Türk Hekimleri Dostluk ve Yardım Cemiyeti: Şeyhületibba, 50 Sene ve Daha Fazla Tababet Hayatı Yaşayan Hekimlerimizin Jübilesi, İstanbul, Şevket Ünal Matbaası, 1964.

Türkman, Sayim: “Birinci Dünya Savaşı'na Giriş Süreci, Doğu (Kafkas) Cephesi: Köprüköy ve Azap Muharebeleri”, Turkish Studies-History, C.15, S.1, 2020, s. 273299.

Ünal, Fatih: "Şikak Aşireti ve Reisi Simko Lakaplı İsmail Ağa'nın Faaliyetleri”, İstanbul Üniversitesi Edebiyat Fakültesi Tarih Dergisi, S.44, 2006, s. 169-198.

\section{Mülakatlar}

General Mustafa Nahit Tunaşar'ın kızı Aysel Ceyhun ile Tunaşar ve ailesi hakkında yapılan görüşme, Ankara, 27.03.2020.

\section{Elektronik Kaynaklar}

“İlçemizin Tarihçesi”, (Çevrimiçi), http://www.akyaka.gov.tr/ilemizin-tarihesi, 30 Ekim 2020.

Bacanl1, Hakan-As, Efdal: (Türk Tıp Tarihinin En Uzun Süreli Bilimsel Yayını) Ceride-i Tıbbiye-i Askerîye'den Gülhane Tıp Dergisi'ne (1872-2017) Tarihçe/Dizin, 2018 (Çevrimiçi), s. 1-36, http://sbu.edu.tr/FileFolder/Dosyalar/eb408a43/2018_10/ cerideitibbiyeyiaskeriyeden.pdf, 21 Haziran 2020.

Sefercioğlu, Necmeddin: “Türkiye'nin En Eski ve En Büyük Sivil Toplum Kuruluşu Türk Ocağı”, 30 Kasım 2001 (Çevrimiçi), https://www.turkocaklari.org.tr/turkocagi-tarihi/turk-ocaklarinin-kisa-tarihcesi-3496, 23 Haziran 2020. 


\title{
EKLER
}

Ek-1: Mustafa Nahit Tunaşar'a Ait "Tercümeihal Kağıdı"

\author{
I'essllil \\ terciimleithal kị̂guld
}

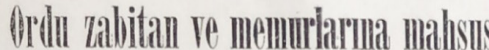

Hane 1. Resmi

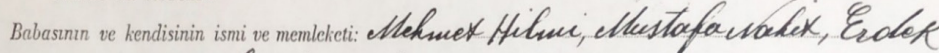
Vazifesi ve rütbesi: K.E F.41 C. 12 Bs. Hex.; Kay.

Dosya - sicil numarast: $329-30$

Hawe 2. Resmi Sinfi: Hetion

Muvazzaf : Athragjaf

Intiyat: Edek, 1306

Doğduğu memleket, tevellüt tarihi : Goinan

Nufusa kayt olduğu mahal: Hace Satim jade.

Tarifat:

1 - İsbu resmî tercümeihaller tercümeihal esas kayt defterindeki malûmata nazaran sicil talimatınn 7. inci maddesinde yazlh tek ve sift seneler tertibatina göre iki senede birdefa illk sicil amiri tarafindan imla ve sicil ile beraber gönderilir.

2 - Bir tercïmeihalde bildirilen hususat diğer tercümeihallerde telirar edilmeyerek yalnnz iki tercümeihal tarihleri arasındaki tehavoülatın imlasiyle iktifa olunur. 
Ek-2: Mustafa Nahit Tunaşar'ın Seferî Hizmetler ve Katıldığı Muharebeler Çizelgesi

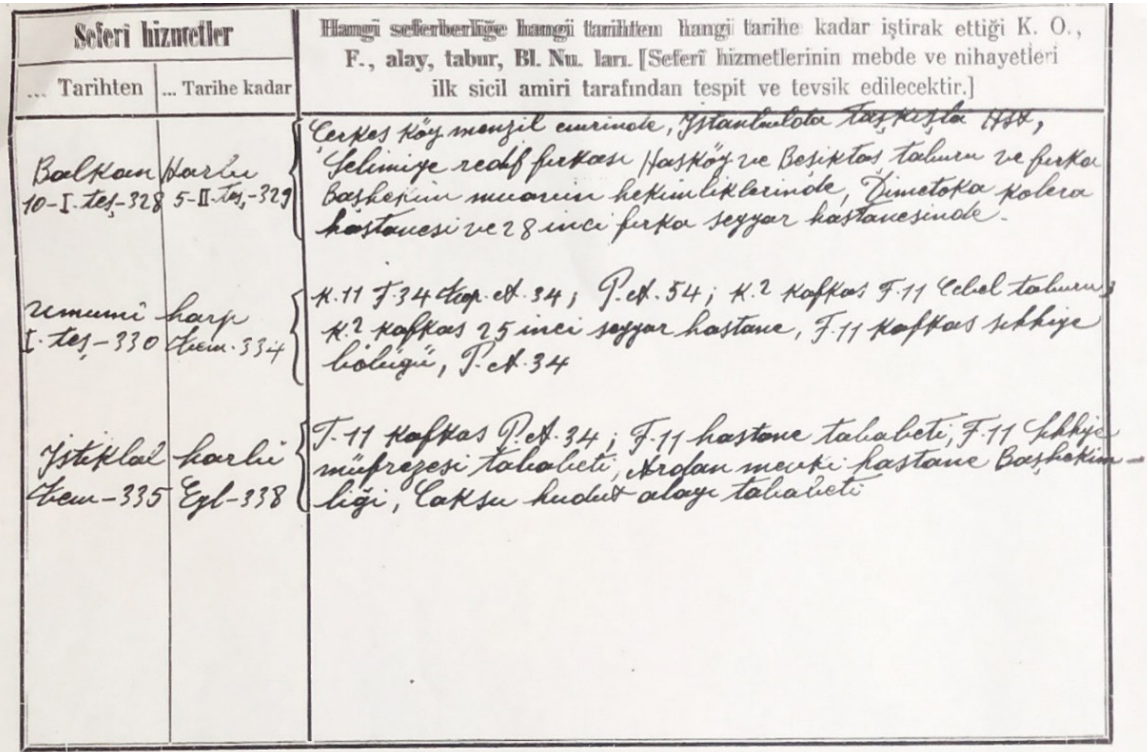

Hane 8

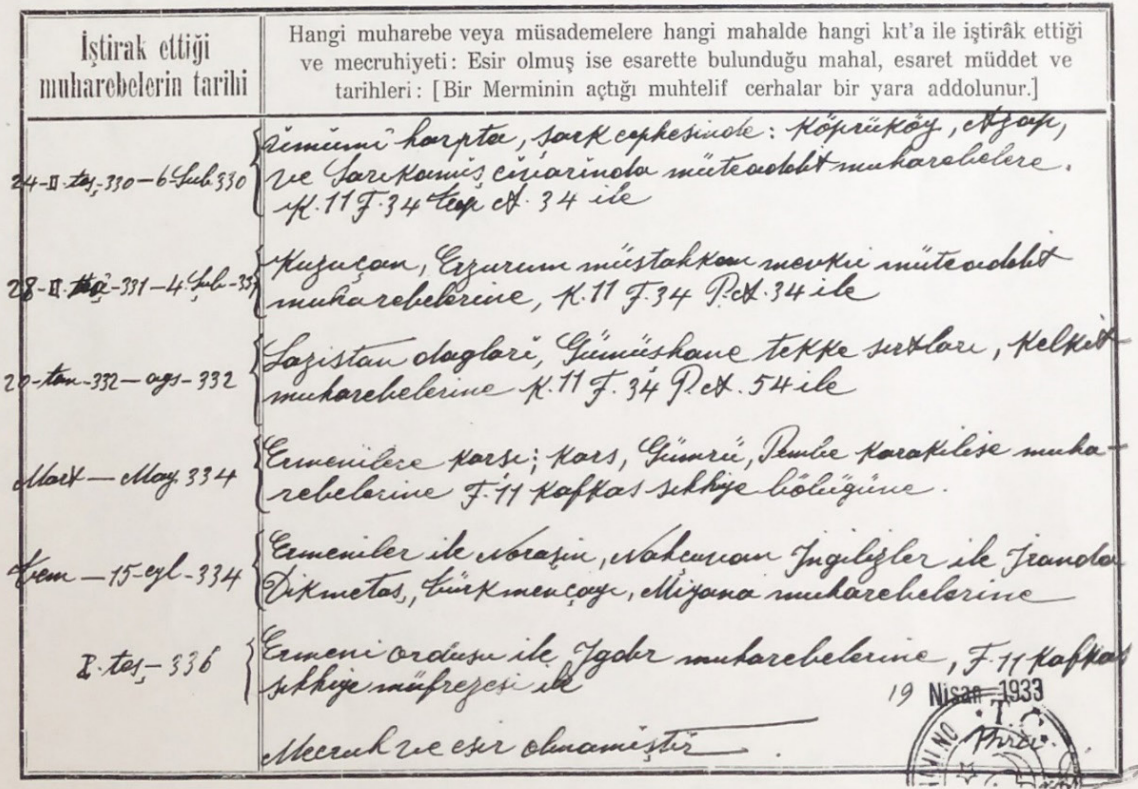




\section{Ek-3: Mustafa Nahit Tunaşar'ın Hamdullah Suphi Bey'e Mektubu}

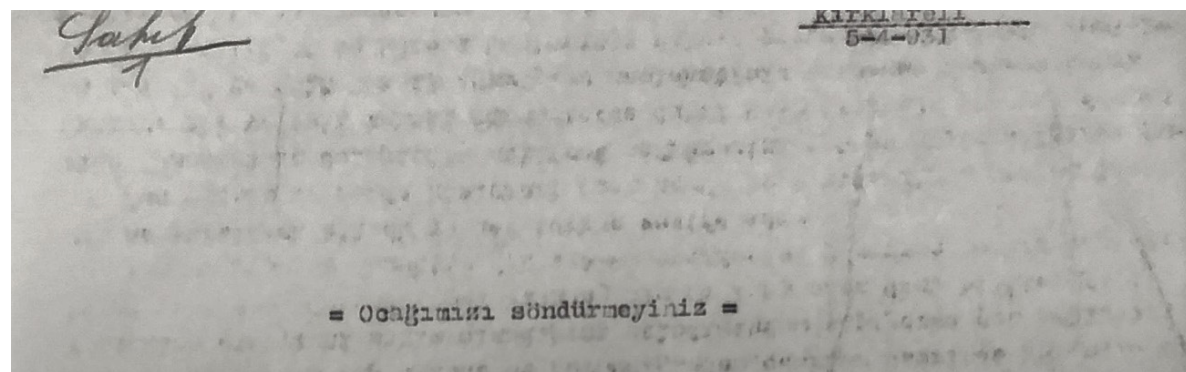

\section{Inhtexoin Handulloh Suph Bey;}

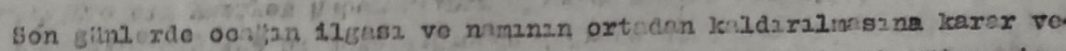

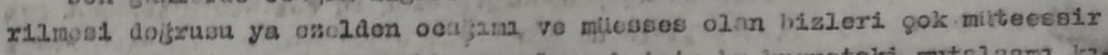

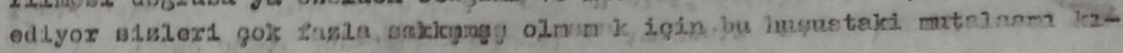
gnan ax: eilogim:

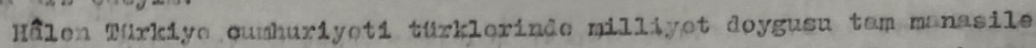

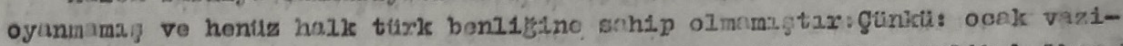

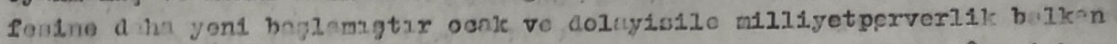

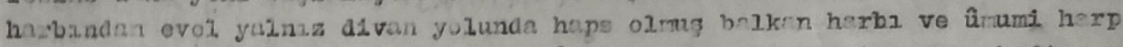
esnnasind moxiln al gig gibi dy

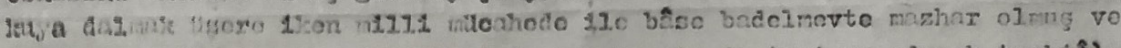

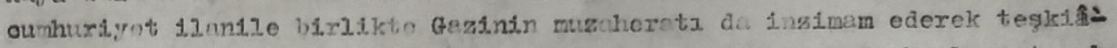

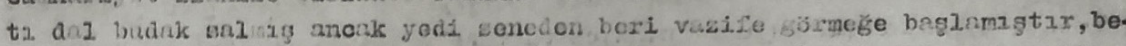

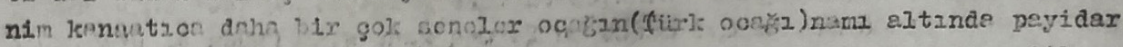

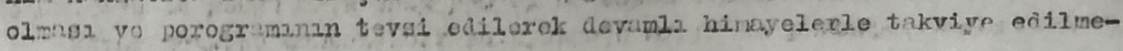
s1 garuxid1.

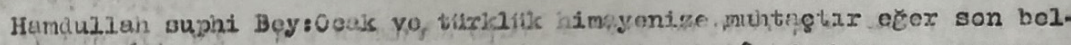

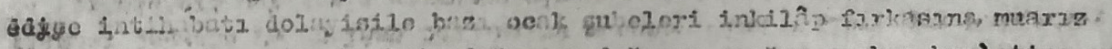

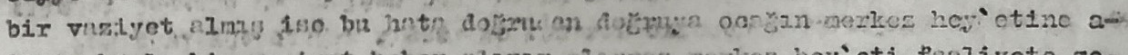
1ttir,böyle bis vaziyet hiber almaz asmiz merkez hoy'eti faliyete ge-

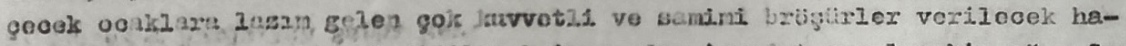

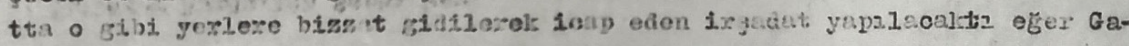

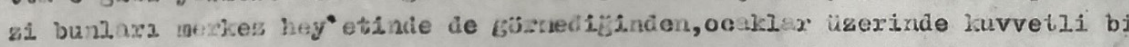

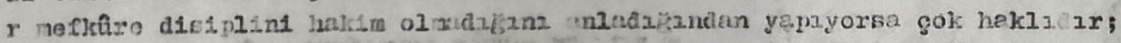

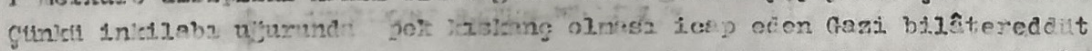
v a.ifosili y zגy

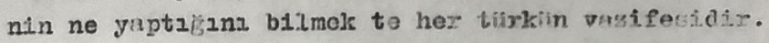

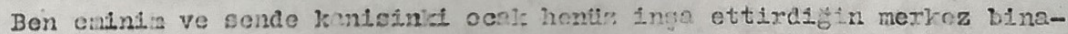

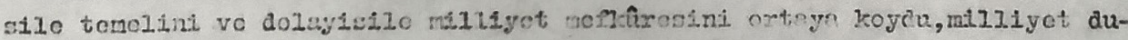

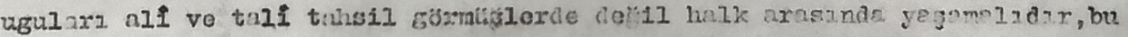
bu gun ali vo tall tahsil gürnïgler nemleketiniz nufusuna nazaran benel

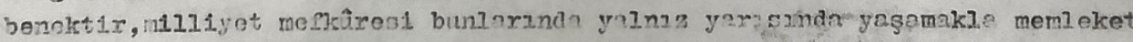

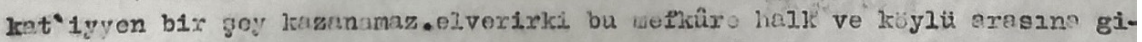

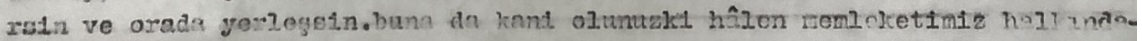
n reate ikisi,bilyilk ve kilgiuls nomûr, zabitler vo kumand mlaramedan yerzca. 


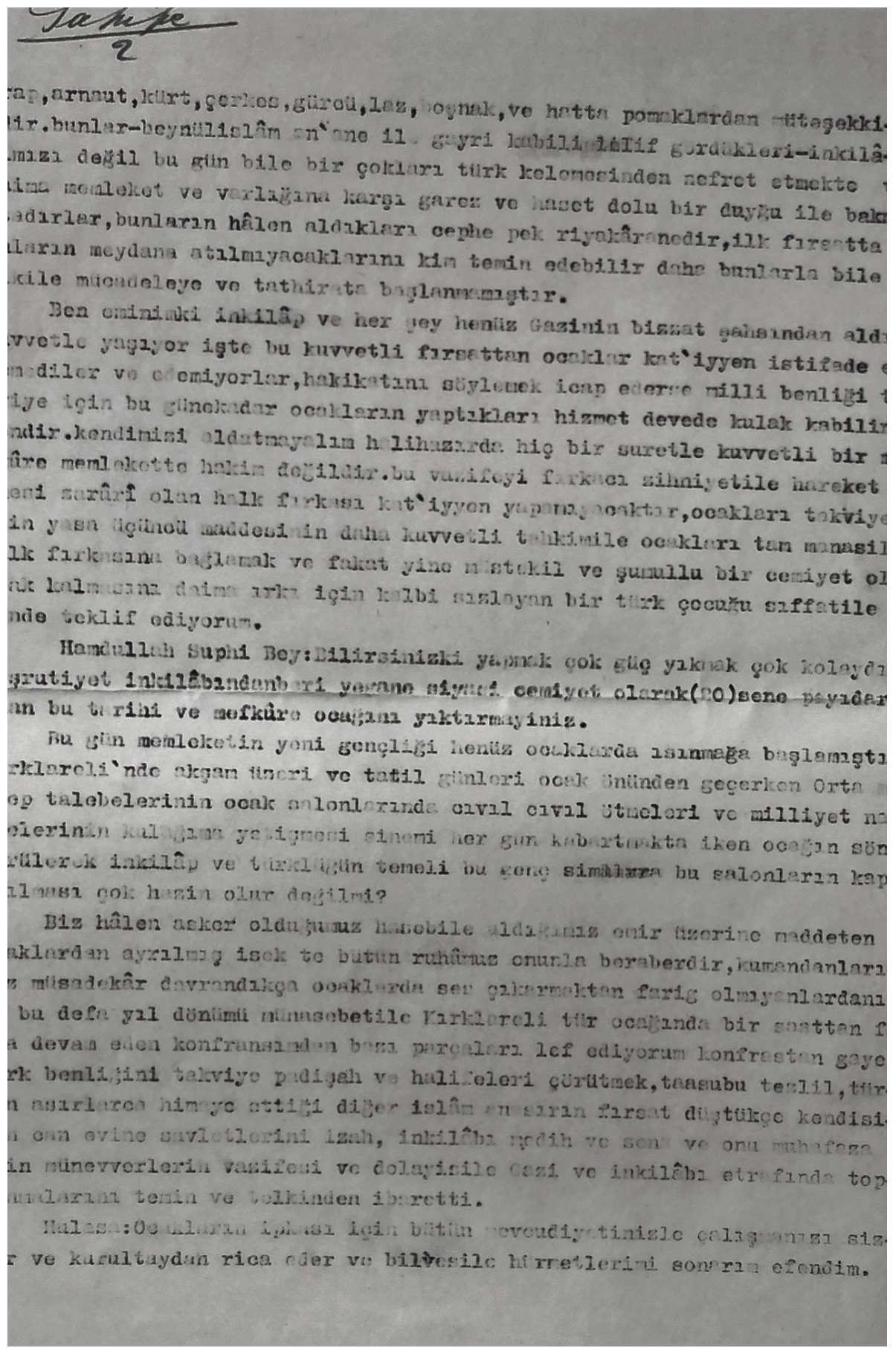


Ek-4: Mustafa Nahit Tunaşar'nn Fotoğraf Albümünden

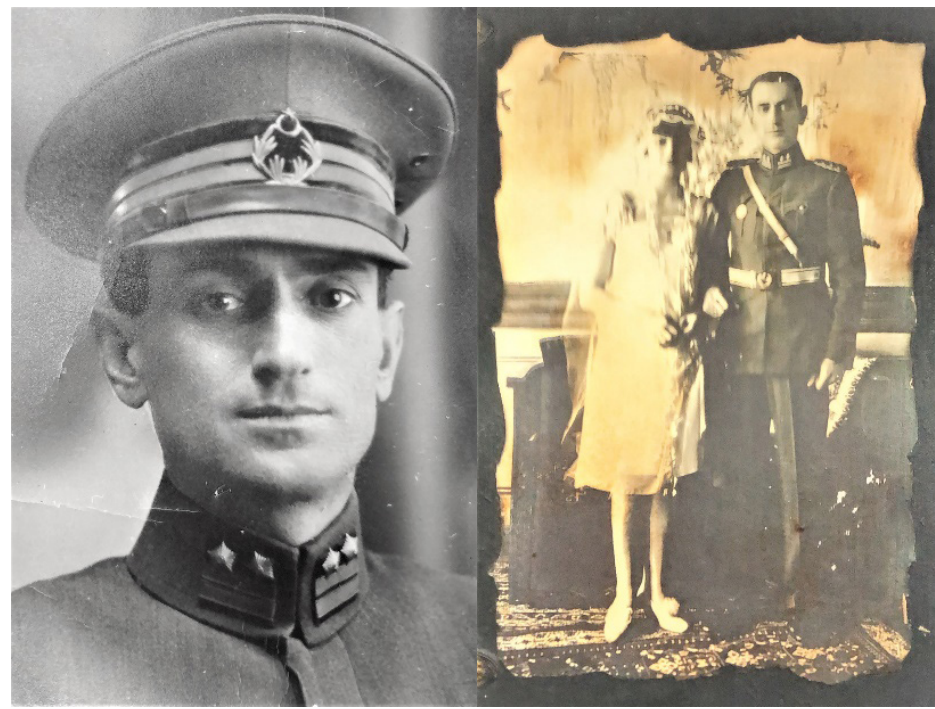

Tabip Yarbay Mustafa Nahit Bey, Eşi Nadire Kerim Hanım ile, 1929-Kırklareli
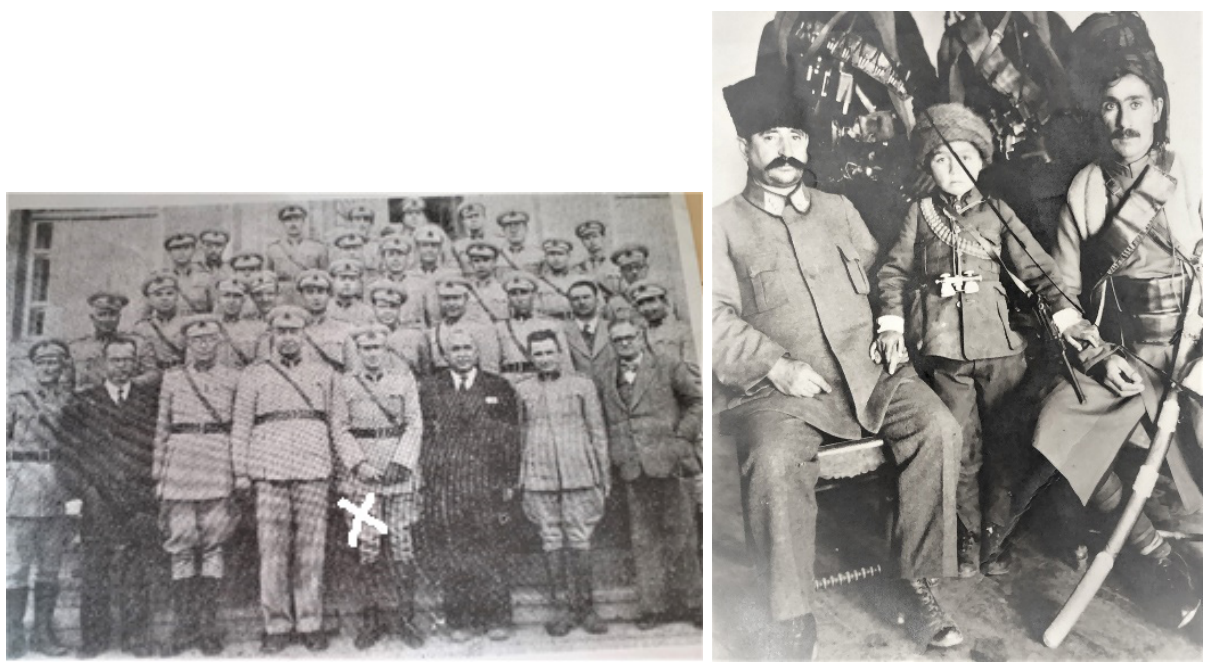

Mesai Arkadaşlarıyla / Süleyman Şefik Paşa, Simko Ağa’nın Oğlu, Simko Ağa 


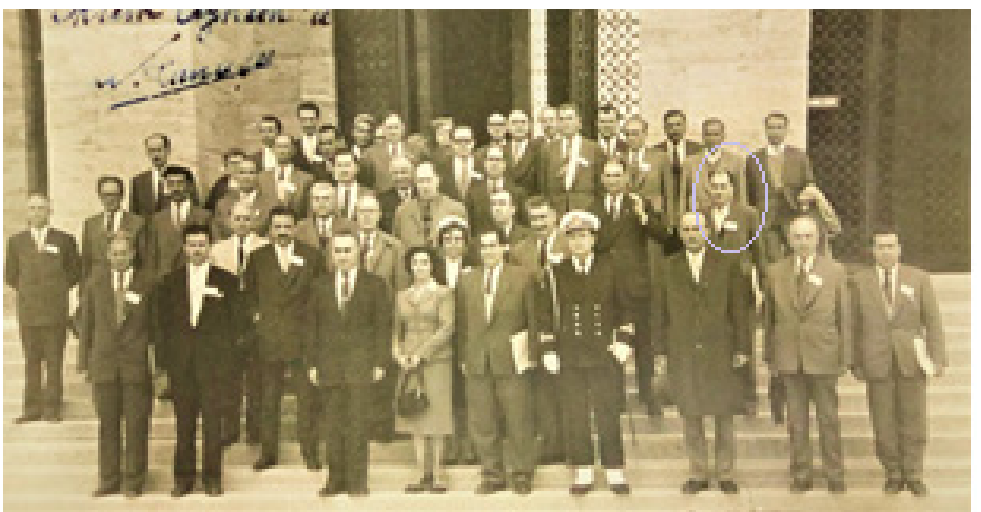

Kızılay Heyeti ile Anıtkabir Ziyareti, 27 Nisan 1961 